\title{
Spatial and temporal variability of rainfall and their effects on hydrological response in urban areas - a review
}

\author{
Elena Cristiano, Marie-claire ten Veldhuis, and Nick van de Giesen \\ Department of Water Management, Delft University of Technology, P.O. Box 5048, 2600 GA, Delft, the Netherlands \\ Correspondence to: Elena Cristiano (e.cristiano@tudelft.nl)
}

Received: 8 October 2016 - Discussion started: 17 October 2016

Revised: 22 June 2017 - Accepted: 22 June 2017 - Published: 28 July 2017

\begin{abstract}
In urban areas, hydrological processes are characterized by high variability in space and time, making them sensitive to small-scale temporal and spatial rainfall variability. In the last decades new instruments, techniques, and methods have been developed to capture rainfall and hydrological processes at high resolution. Weather radars have been introduced to estimate high spatial and temporal rainfall variability. At the same time, new models have been proposed to reproduce hydrological response, based on smallscale representation of urban catchment spatial variability. Despite these efforts, interactions between rainfall variability, catchment heterogeneity, and hydrological response remain poorly understood. This paper presents a review of our current understanding of hydrological processes in urban environments as reported in the literature, focusing on their spatial and temporal variability aspects. We review recent findings on the effects of rainfall variability on hydrological response and identify gaps where knowledge needs to be further developed to improve our understanding of and capability to predict urban hydrological response.
\end{abstract}

\section{Introduction}

The lack of sufficient information about spatial distribution of short-term rainfall has always been one of the most important sources of errors in urban runoff estimation (Niemczynowicz, 1988). In the last decades considerable advances in quantitative estimation of distributed rainfall have been made, thanks to new technologies, in particular weather radars (Leijnse et al., 2007; van de Beek et al., 2010; Otto and Russchenberg, 2011). These developments have been applied in urban hydrology researches; see Einfalt et al. (2004) and Thorndahl et al. (2017) for a review. The hydrological response is sensitive to small-scale rainfall variability in both space and time (Faures et al., 1995; Emmanuel et al., 2012; Smith et al., 2012; Ochoa-Rodriguez et al., 2015b), due to a typically high degree of imperviousness and to a high spatial variability of urban land use.

Progress in rainfall estimation is accompanied by increasing availability of high-resolution topographical data, especially digital terrain models and land use distribution maps (Mayer, 1999; Fonstad et al., 2013; Tokarczyk et al., 2015). High-resolution topographical datasets have promoted development of more detailed and more complex numerical models for predicting flows (Gironás et al., 2010; Smith et al., 2013). However, model complexity and resolution need to be balanced with the availability and quality of rainfall input data and datasets for catchment representation (Morin et al., 2001; Rafieeinasab et al., 2015; Rico-Ramirez et al., 2015; Rafieeinasab et al., 2015; Pina et al., 2016). This is particularly critical in small catchments, where flows are sensitive to variations at small space and timescales as a result of the fast hydrological response and the high catchment variability (Fabry et al., 1994; Singh, 1997). Alterations of natural flows introduced by human interventions, especially artificial drainage networks, sewer pipe networks, detention and control facilities, such as reservoirs, pumps, and weirs, are additional elements to take into account for flow predictions. Recently, various authors investigated the sensitivity of spatial and temporal rainfall variability on the hydrological response for urban areas (Bruni et al., 2015; Ochoa-Rodriguez et al., 2015b; Rafieeinasab et al., 2015). Despite these efforts, many aspects of hydrological processes in urban areas remain poorly understood, especially in the interaction between rainfall and runoff. 
It is timely to review recent progress in understanding of interactions between rainfall spatial and temporal resolution, variability of catchment properties and their representation in hydrological models. Section 2 of this paper is dedicated to definitions of spatial and temporal scales and catchments in hydrology and methods to characterize these. Section 3 focuses on rainfall, analysing the most used rainfall measurement techniques, their capability to accurately measure small-scale spatial and temporal variability, with particular attention to applications in urban areas. Hydrological processes are described in Sect. 4, highlighting their variability and characteristics in urban areas. Thereafter, the state of the art of hydrological models, as well as their strengths and limitations to account for spatial and temporal variability, are discussed. Section 6 presents recent approaches to understand the effect of rainfall variability in space and time on hydrological response. In Sect. 7, main knowledge gaps are identified with respect to accurate prediction of urban hydrological response in relation to spatial and temporal variability of rainfall and catchment properties in urban areas.

\section{Scales in urban hydrology}

\subsection{Spatial and temporal scale definitions}

Hydrological processes occur over a wide range of scales in space and time, varying from $1 \mathrm{~mm}$ to $10000 \mathrm{~km}$ in space and from seconds up to 100 years in time. A scale is defined here as the characteristic region in space or period in time at which processes take place or the resolution in space or time at which processes are best measured (Salvadore et al., 2015).

Several authors have classified hydrological process scales and variability, focusing in particular on the interaction between rainfall and the other hydrological processes (Blöschl and Sivapalan, 1995; Bergstrom and Graham, 1998). Blöschl and Sivapalan (1995) presented a graphical representation of spatial and temporal variability of the main hydrological processes on a logarithmic plane. The plot has been updated by other authors, each focusing on specific aspects. For example, Salvadore et al. (2015) analysed phenomena related to urban processes, focusing on small spatial scale, while Van Loon (2015), added scales of some hydrological problems, such as flood and drought. Figure 1 presents an updated version of the plot that integrates the information contributed by Berndtsson and Niemczynowicz (1986), Blöschl and Sivapalan (1995), Stahl and Hisdal (2004), and Salvadore et al. (2015). Figure 1 shows that in urban hydrology attention is mainly focused on small scales. Characteristic processes, such as storm drainage, infiltration, and evaporation, vary at a small temporal and spatial scale, from seconds to hours and from centimetres to hundreds of metres. Many processes are driven by rainfall, that varies over a wide range of scales.
Blöschl and Sivapalan (1995) highlighted the importance of making a distinction between two types of scales: the "process scale", i.e. the proper scale of the considered phenomenon, and the "observation scale", related to the measurement and depending on techniques and instruments used. Under the best scenario, process and observation scale should match, but this is not always the case, and transformations based on downscaling and upscaling techniques (Fig. 2) might be necessary to obtain the required match between scales. These techniques are discussed in Sect. 2.2.

\subsection{Rainfall downscaling}

The term downscaling usually refers to methods used to take information known at large scale and make predictions at small scale. There are two main downscaling approaches: dynamic or physically based and statistical methods (Xu, 1999). Dynamic downscaling approaches solve the process-based physics dynamics of the system. In statistical downscaling, a statistical relationship is defined between local variables and large-scale prediction and this relationship is applied to simulate local variables (Xu, 1999). Dynamical downscaling is widely used in climate modelling and numerical weather prediction, while statistical models are often used in hydrometeorology, for example rainfall downscaling. Dynamic downscaling models have the advantage of being physically based, but they require a lot of computational power compared to statistical downscaling models. Statistical approaches require historical data and knowledge of local conditions (Xu, 1999).

Ferraris et al. (2003) presented a review of three common stochastic downscaling models, mainly used for spatial rainfall downscaling: multifractal cascades, autoregressive processes, and point-process models based on the presence of individual cells. The first were introduced in the 1970s and are widely used to reproduce the spatial and temporal variability (see Schertzer and Lovejoy, 2011 for a review). Autoregressive methods, also nowadays often referred to as "rainfall generator models", are used to generate multidimensional random fields while preserving the rainfall spatial autocorrelation, for natural (Paschalis et al., 2013; Peleg and Morin, 2014; Niemi et al., 2016) and urban (Sørup et al., 2016) areas. Point-process models are used when the spatial structure of intense rainfall is defined by convective rainfall cells (see McRobie et al., 2013 for an example). It incorporates local information and requires a more detailed storm cell identification.

Statistical downscaling and upscaling approaches are reported in the literature for a wide variety of variables (Rummukainen, 1997; Deidda, 2000; Ferraris et al., 2003; Gires et al., 2012; Wang et al., 2015b; Muthusamy et al., 2017) and techniques such as regression methods, weather patternbased approaches and stochastic rainfall generators (see Wilby and Wigley, 1997; Wilks and Wilby, 1999 for a review). Some recent studies about downscaling and upscaling focus mainly on urban areas (Gires et al., 2012; Wang et al., 


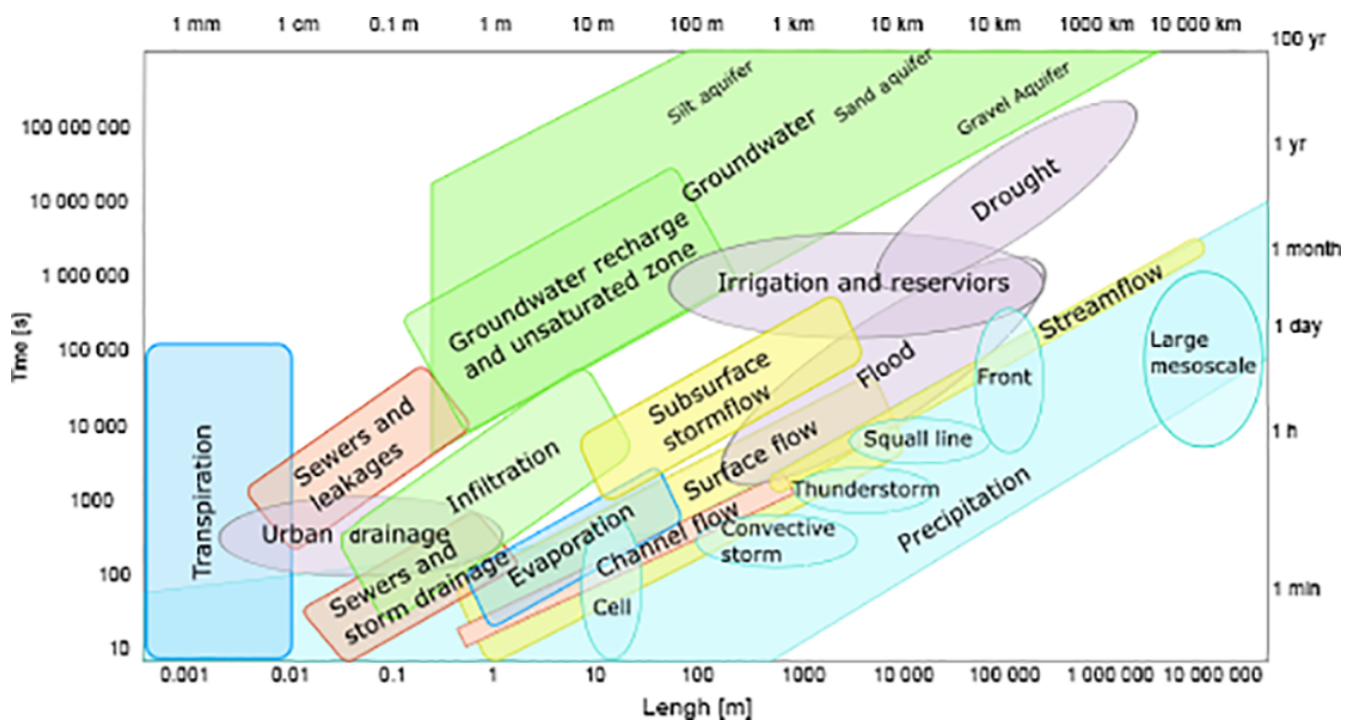

Figure 1. Spatial and temporal scale variability of hydrological processes, adapted from Berndtsson and Niemczynowicz (1986), Blöschl and Sivapalan (1995), Stahl and Hisdal (2004), and Salvadore et al. (2015). Colours represent different groups of physical processes: blue for processes related to the atmosphere, yellow for surface processes, green for underground processes, red highlights typical urban processes, and grey indicates problems hydrological processes can pose to society.

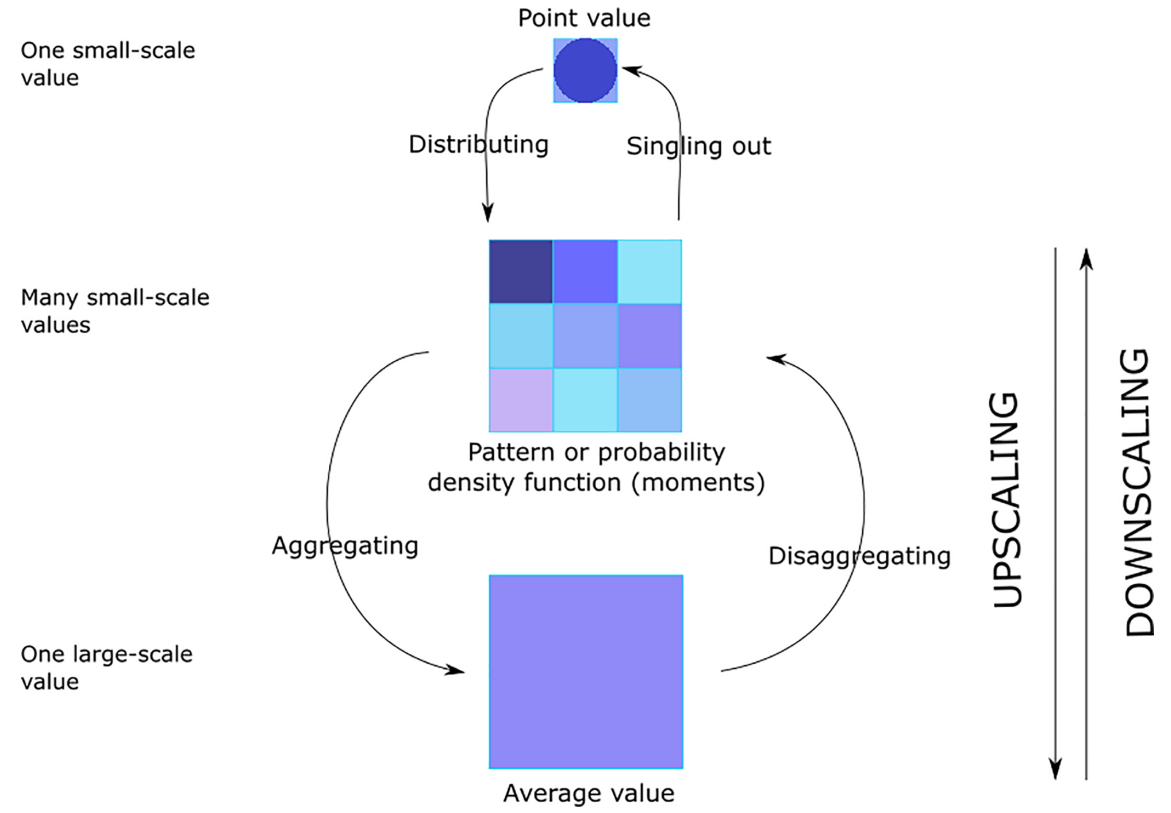

Figure 2. Downscaling and upscaling processes (modified from Blöschl and Sivapalan, 1995).

2015b, a; Muthusamy et al., 2017): Wang et al. (2015a), for example, presented a gauge-based radar-rainfall adjustment method sensitive to singularities, characteristic of small scale.

The importance of using downscaling methods was discussed by Fowler et al. (2007), in a work where they investigated what can be learned from downscaling method comparison studies, what new methods can be used together with downscaling to assess uncertainties in hydrological response and how downscaling methods can be better utilized within the hydrological community. They highlighted that the importance given to the applied research is still too little, and manager and stakeholders should be more aware of uncertainties within the modelling system. 


\subsection{Methods to characterize hydrological process scales}

\subsubsection{Spatial variability of basin characteristics}

Slope, degree of imperviousness, soil properties, and many other catchment characteristics are variable in space and time and this variability affects the hydrological response (Singh, 1997). This is especially the case of urban areas, where spatial variability and temporal changes in land use are typically high.

Julien and Moglen (1990) gave a first definition of the catchment length scale $L_{\mathrm{s}}$ as part of a theoretical framework applied to a natural catchment, where they analysed 8400 dimensionless hydrographs obtained from one-dimensional finite element models under spatially varied input. Length scale was presented as a function of rainfall duration $d$, spatially averaged rainfall intensity $i$, average slope $s_{0}$, and average roughness $n$ :

$L_{\mathrm{s}}=\frac{d^{\frac{5}{6}} s_{0}^{\frac{1}{2}} i^{\frac{2}{3}}}{n}$.

In urban catchments, the concept of catchment length, defined as the squared root of the (sub)catchment or runoff area, has been used (Bruni et al., 2015; Ochoa-Rodriguez et al., 2015a). Additionally, Bruni et al. (2015) introduced the sewer length or inter-pipes sewer distance, as the ratio between the catchment area and the total length of the sewer, to characterize the spatial scale of sewer networks. Ogden et al. (2011) used the width function, defined as the number of channel segments at a specific distance from the outlet, to represent the spatial variability of the drainage network. This parameter describes the network geomorphology by counting all stream links located at the same distance from the outlet, but it does not give an accurate description of the spatial variability of hydrodynamic parameters.

\subsubsection{Timescale characteristics}

In this section, we present a brief overview of timescales reported in the literature and discuss approaches to estimate characteristic timescales that have been specifically developed for urban areas. A summary of timescale characteristics is presented in Table 1.

The first method to investigate the hydrological response is the rational method, presented more than a century ago by (Kuichling, 1889) for urban areas. This method was later adapted for rural areas. The rational method requires the estimation of the time of concentration in order to define the runoff volume.

Time of concentration $t_{\mathrm{c}}$ is one of the most common hydrological characteristic timescales and it is defined as the time that a drop that falls on the most remote part of the basin needs to reach the basin outlet (Singh, 1997; Musy and Higy, 2010). Several equations to estimate this parameter are avail- able in the literature for natural (Gericke and Smithers, 2014) and urban (McCuen et al., 1984) catchments. The time of concentration is difficult to measure, because it assumes that initial losses are already satisfied and the rainfall event intensity is constant for a period at least as long as the time of concentration. Different theoretical definitions have been developed in order to estimate the time of concentration as function of basin length, slope and other characteristics (see for some examples Singh, 1976; Morin et al., 2001; USDA, 2010; Gericke and Smithers, 2014).

Due to difficulties related to the estimation of time of concentration, Larson (1965) introduced the time of virtual equilibrium $t_{\mathrm{ve}}$, defined as the time until response is $97 \%$ of runoff supply.

When a given rainfall rate persists on a region for enough time to reach the equilibrium, this time is called time to equilibrium $t_{\mathrm{e}}$ (Ogden et al., 1995; Ogden and Dawdy, 2003; van de Giesen et al., 2005). Time of equilibrium for a turbulent flow on a rectangular runoff plane given rainfall intensity $i$, with given roughness $n$, length $L_{\mathrm{p}}$ and slope $S$ can be written as (Ogden et al., 1995)

$t_{\mathrm{e}}=\left[\frac{n L_{\mathrm{p}}}{S^{\frac{1}{2}} i^{\frac{2}{3}}}\right]^{\frac{3}{5}}$

Another commonly used hydrological characteristic timescale or response time is the lag time $t_{\text {lag }}$. It represents the delay between rainfall and runoff generation. $t_{\text {lag }}$ is defined as the distance between the hyetograph and hydrograph centre of mass of (Berne et al., 2004), or between the time of rainfall peak and time of flow peak (Marchi et al., 2010; Yao et al., 2016). $t_{\text {lag }}$ can be considered characteristic of a basin, and is dependent on drainage area, imperviousness and slope (Morin et al., 2001; Berne et al., 2004; Yao et al., 2016). Berne et al. (2004), including the results of Schaake et al. (1967) and Morin et al. (2001), defined a relation between the dimension of the catchment area $S$ (in ha) and the lag time $t_{\text {lag }}$ (in millimetres): $t_{\text {lag }}=3 S^{0.3}$ for urban areas. Empirical relations between $t_{\text {lag }}$ and $t_{\mathrm{c}}$ are presented in the literature (USDA, 2010; Gericke and Smithers, 2014).

Another characteristic timescale is the "response timescale" $T_{\mathrm{S}}$, presented for the first time by Morin et al. (2001). It is defined as the timescale at which the pattern of the time averaged and basin averaged radar-rainfall hyetograph is most similar to the pattern of the measured hydrograph at the outlet of the basin. This definition was updated by Morin et al. (2002), which used an objective and automatic algorithm to analyse the smoothness of the hyetograph and hydrograph instead of the general behaviour, and by Shamir et al. (2005), who related the number of peaks with the total duration of the rising and declining limbs of hyetographs and hydrographs.

In urban areas, where most of the surface is directly connected to the drainage system, concentration time is given by 
Table 1. Timescale parameters.

\begin{tabular}{lll}
\hline Characteristic & Reference & Description \\
\hline $\begin{array}{l}\text { Time of concentration } \\
t_{\mathrm{c}}\end{array}$ & $\begin{array}{l}\text { Singh (1997) } \\
\text { Gericke and Smithers (2014) }\end{array}$ & $\begin{array}{l}\text { The time that a drop that falls on the most remote } \\
\text { part of the drainage basin needs to reach the } \\
\text { basin outlet }\end{array}$ \\
\hline $\begin{array}{l}\text { Time of equilibrium } \\
t_{\mathrm{e}}\end{array}$ & $\begin{array}{l}\text { Ogden et al. (1995) } \\
\text { Ogden and Dawdy (2003) } \\
\text { van de Giesen et al. (2005) }\end{array}$ & $\begin{array}{l}\text { Minimum time needed for a given stationary } \\
\text { uniform rainfall to persist until equilibrium runoff } \\
\text { flow is reached }\end{array}$ \\
\hline $\begin{array}{l}\text { Lag time } \\
t_{\text {lag }}\end{array}$ & $\begin{array}{l}\text { Berne et al. (2004) } \\
\text { Marchi et al. (2010) } \\
\text { Gericke and Smithers (2014) }\end{array}$ & $\begin{array}{l}\text { The time difference between the gravity centre } \\
\text { of the hyetograph of catchment mean rainfall and the } \\
\text { gravity centre of the generated hydrograph }\end{array}$ \\
\hline Response timescale & $\begin{array}{l}\text { Morin et al. (2001) } \\
\text { Morin et al. (2002) } \\
T_{\mathrm{S}}\end{array}$ & $\begin{array}{l}\text { The timescale at which the pattern of time } \\
\text { averaged radar hyetograph is most similar to the } \\
\text { pattern of the measured hydrograph at the outlet } \\
\text { of the basin }\end{array}$ \\
\hline Shamir et al. (2003)
\end{tabular}

the time the rainfall needs to enter the sewer system and the travel time through the sewer system.

\section{Rainfall measurement and variability in urban regions}

Rainfall is an important driver for many hydrological processes and represents one of the main sources of uncertainty in studying hydrological response (Niemczynowicz, 1988; Einfalt et al., 2004; Thorndahl et al., 2017; Rico-Ramirez et al., 2015).

Urban areas affect the local hydrological system, not only by increasing the imperviousness degree of the soil but also by changing rainfall generation and intensity patterns. Several studies show that increase in heat and pollution produced by human activities and changes in surface roughness influence rainfall and wind generation (Huff and Changno, 1973; Shepherd et al., 2002; Givati and Rosenfeld, 2004; Shepherd, 2006; Smith et al., 2012; Daniels et al., 2015; Salvadore et al., 2015). This phenomenon is not deeply investigated in this paper, but it is an important aspect to consider.

In this section instruments and technologies for rainfall measurement are described, pointing out their opportunities and limitations for measuring spatial and temporal variability in urban environments. Subsequently, methods to characterize rainfall events according to their space and time variability are described.

\subsection{Rainfall estimation}

Rain gauges were the first instrument used to measure rainfall and are still commonly used, because they are relatively low in cost and easy to install (WMO, 2008).

Afterwards, weather radars were introduced to estimate the rainfall spatial distribution. These instruments allow one to get measurements of rainfall spatially distributed over the area, instead of a point measurement as in the case of rain gauges. Rainfall data obtained from weather radars are used to study the hydrological response in natural watersheds and urban catchments (Einfalt et al., 2004; Berne et al., 2004; Sangati et al., 2009; Smith et al., 2013; OchoaRodriguez et al., 2015b; Thorndahl et al., 2017) often combined with rainfall measurement from rain gauge networks (Winchell et al., 1998; Smith et al., 2005; Segond et al., 2007; Smith et al., 2012), as well as to improve short-term weather forecasting and nowcasting (Montanari and Grossi, 2008; Liguori and Rico-Ramirez, 2013; Dai et al., 2015; Foresti et al., 2016).

More recently, commercial microwave links have been used to estimate the spatial and temporal rainfall variability (Leijnse et al., 2007; Fencl et al., 2015, 2017). Rainfall estimates are obtained from the attenuation of the signal caused by rain along microwave link paths. This approach can be particularly useful in cities that are not well equipped with rain gauges or radars, but where the commercial cellular communication network is typically dense (Leijnse et al., 2007).

\subsubsection{Rain gauges networks}

Several types of rain gauges have been developed, such as weighing gauges, tipping bucket gauges and pluviographs (Lanza and Stagi, 2009; Lanza and Vuerich, 2009). They are able to constantly register accumulation of rainfall volume over time, thus providing a measurement of temporal variability of rainfall intensity. Rain gauge measurements are sensitive to wind exposure and the error caused by wind field above the rain gauge is $2-10 \%$ for rainfall and up to $50 \%$ for solid precipitations (WMO, 2008). Other errors can be due to tipping bucket losses during the rotation, to wetting losses on the internal walls of the collector, to evaporation (especially 
in hot climates), or water splashing into and out of the collector (WMO, 2008). The main disadvantage of rain gauges is that the obtained data are point measurements and, due to the high spatial variability of rainfall events, measurements from a single rain gauges are often not representative of a larger area. Rainfall fields, however, present a spatial organization and, by interpolating data from a rain gauge networks, it is possible to obtain distributed rainfall fields (Villarini et al., 2008; Muthusamy et al., 2017). Uncertainty induced by interpolation strongly depends on the density of the rain gauge network and on homogeneity of the rainfall field (Wang et al., 2015b).

In urban areas, rainfall measurements with rain gauges present specific challenges associated with microclimatic effects introduced by the building envelope. WMO (2008) recommended minimum distances between rain gauges and obstacles of 1 to 2 times the height of the nearest obstacle, a condition that is hard to fulfil in densely built areas. A second problem is introduced by hard surfaces, that may cause water splashing into the gauges, if it is not placed at an elevation of at least $1.2 \mathrm{~m}$. Rain gauges in cities are often mounted on roofs for reasons of space availability and safety from vandalism. This means they are affected by the wind envelope of the building, unless they are elevated to a sufficient height above the building.

Rain gauge measurement error can be $30 \%$ or more depending on the type of instrument used for the measurement and local conditions (van de Ven, 1990; WMO, 2008).

\subsubsection{Weather radars}

In the last decades, weather radars have been increasingly used to measure rainfall (Niemczynowicz, 1999; Krajewski and Smith, 2005; Otto and Russchenberg, 2011; Berne and Krajewski, 2013). Radars transmit pulses of microwave signals and measure the power of the signal reflected back by raindrops, snowflakes, and hailstones (backscatter). Rainfall rate $R\left[\mathrm{~L} \mathrm{~T}^{-1}\right]$ is estimated using the reflectivity $Z\left[\mathrm{~L}^{6} \mathrm{~L}^{-3}\right]$ measured from the radar through a power law:

$R=a Z^{b}$,

where $a$ and $b$ depend on type of precipitation, raindrop distribution, climate characteristics and spatial and temporal scales considered (Marshall and Palmer, 1948; van de Beek et al., 2010; Smith et al., 2013). Weather radars present different wavelengths $\lambda$, frequencies $v$ and sizes of the antenna l. Characteristics of commonly used weather radars are reported in Table 2. X-band radars can be beneficial for urban areas; they are low cost and they can be mounted on existing buildings and measure rainfall closer to ground at higher resolution than national weather radar networks (Einfalt et al., 2004). Polarimetric weather radars transmit signals polarized in different directions (Otto and Russchenberg, 2011), enabling it to distinguish between horizontal and vertical dimension, thus between rain drops and snowflakes
Table 2. Weather radar characteristics.

\begin{tabular}{lrrr}
\hline & $\begin{array}{r}\lambda \\
\mathrm{cm}\end{array}$ & $\begin{array}{r}l \\
\mathrm{GHz}\end{array}$ & $\mathrm{m}$ \\
\hline S-band & $8-15$ & $2-4$ & $6-10$ \\
C-band & $4-8$ & $4-8$ & $3-5$ \\
X-band & $2.5-4$ & $8-12$ & $1-2$ \\
\hline
\end{tabular}

as well as between smaller or larger oblate rain drops. A specific strength of polarimetric radars is the use of differential phase $K_{\mathrm{dp}}$, which allows one to correct signal attenuation thus solving an important problem generally associated with X-band radars (Otto and Russchenberg, 2011; OchoaRodriguez et al., 2015b; Thorndahl et al., 2017).

\subsubsection{Opportunities and limitations of weather radars}

Berne and Krajewski (2013) presented a comprehensive analysis of the advantages, limitations and challenges in rainfall estimation using weather radars. One of the main problems is that an indirect relation is used (Eq. 3) to estimate rainfall. Rainfall measurements have to be adjusted based on rain gauges and disdrometers. Various techniques have been studied to calibrate radars (Wood et al., 2000), to combine radar-rainfall measurements with rain gauge data for ground truthing (Cole and Moore, 2008; Smith et al., 2012; Wang et al., 2013; Gires et al., 2014; Nielsen et al., 2014; Wang et al., 2015b) and to define the uncertainty related to radarrainfall estimation (Ciach and Krajewski, 1999; Quirmbach and Schultz, 2016; Villarini et al., 2008; Mandapaka et al., 2009; Peleg et al., 2013; Villarini et al., 2014). These studies show that in most of the cases, radar measurements underestimate the rainfall compared to rain gauge measurements (Smith et al., 2012; Overeem et al., 2009a; Overeem et al., 2009b; van de Beek et al., 2010).

Another downside of radars is their installation at high locations to have a clear view without obstacles, while rainfall intensities can change before reaching the ground (Smith et al., 2012). Moreover, radar measurements need to be combined with a rain drop size distribution to obtain an accurate rainfall estimation. Berne and Krajewski (2013) pointed out additional aspects that have to be taken into account, e.g., management and storage of the high quantity of data that are measured, possibility to use the weather radars to estimate snowfall and the uncertainty related to it, and problems related to rainfall measurement in mountain areas.

Rain gauge measurements in urban areas tend to be prone to errors due to microclimatic effects introduced by the building envelope. In this context, the use of weather radar could represent a big improvement to obtain a more accurate rainfall information for studying hydrological response.

A promising application of radar is their combination with nowcasting models to obtain short-term rainfall forecasts. Liguori and Rico-Ramirez (2013) presented a review of dif- 
ferent nowcasting models, which benefit from radar data. This work focused in particular on a hybrid model, able to merge the benefits of radar nowcasting and numerical weather prediction models. Radar data can provide an accurate short-term forecast and recent studies have presented nowcasting systems able to reduce errors in rainfall estimation (e.g. Foresti et al., 2016).

\subsection{Characterizing rainfall events according to their spatial and temporal scale}

Rainfall events are characterized by several elements, such as duration, intensity, velocity and their spatial and temporal variability, and many possible classifications are presented in the literature. Some of the most used examples of rainfall classification considering the rainfall variability, are described in this section.

Characterizations and classifications of intense rainfall events have been proposed by various authors, combining rain gauges and radar-rainfall data. In particular, weather radars are used as main tools to analyse rainfall spatial and temporal scale in urban areas. An example of characterization of rainfall structure was given by Smith et al. (1994), who presented an empirical analysis of four extreme rainstorms in the Southern Plains (USA), using data from two networks of more than 200 rain gauges and from a weather radar. They defined major rainfall event as storms for which $25 \mathrm{~mm}$ of rain covered an area larger than $12500 \mathrm{~km}^{2}$. Thorndahl et al. (2014) presented a storm catalogue of heavy rainfall, over a study area of $73500 \mathrm{~km}^{2}$ in southern Wisconsin, and key elements of storm evolution that control the scale. The catalogue contains the 50 largest rainfall events recorded during a 16-year period by WSR-88D radar with spatial and temporal resolution of $1 \mathrm{~km} \times 1 \mathrm{~km}$ and 15 min respectively. Over the 50 events, there is 0.60 probability that rainfall exceeds $25 \mathrm{~mm}$ of daily accumulation in a $1 \mathrm{~km}^{2}$ pixel and 0.14 probability of exceeding $100 \mathrm{~mm}$. Results showed that there is a clear relation between the characteristic length and timescale of the events. The length scale increased with timescale; a length scale of $35 \pm 20 \mathrm{~km}$ was found for a time step of $15 \mathrm{~min}$, up to $160 \pm 25 \mathrm{~km}$ for a $12 \mathrm{~h}$ aggregation time.

\subsection{Rainfall variability at the urban scale}

Rainfall events are often described and classified considering they variability in space and time. Spatial variability can be defined, following Peleg et al. (2017), as "the variability derived from having multiple spatially distributed rainfall fields for a given point in time". Peleg et al. (2017) introduced also the definition of climatological variability as the variability obtained from multiple climate trajectories that produce different storm distributions and rainfall intensities in time.

Studying rainfall variability at the urban scale, Emmanuel et al. (2012) classified 24 rain periods, recorded by the weather radar located in Treillieres (France), with a spatial and temporal resolution of $250 \mathrm{~m} \times 250 \mathrm{~m}$ and $5 \mathrm{~min}$ respectively. They classified the events into four groups, based on variogram analysis: light rain period, shower periods, storms organized into rain bands and unorganized storms. These groups are defined considering the decorrelation distance (and decorrelation time), defined as distance (and time) from which two points show independent statistical behaviour, and it is obtained as the range of the climatological variogram (Emmanuel et al., 2012). The first group, characterized by light rainfall events, presented very high decorrelation distance and time (17 km and $15 \mathrm{~min}$ ) compared to the second group, with a decorrelation distance and time of $5 \mathrm{~km}$ and a decorrelation time of $5 \mathrm{~min}$. The last two groups presented a double structure, where small and intense clusters, with low decorrelation distance and time (less than $5 \mathrm{~km}$ and $5 \mathrm{~min}$ ) are located, in a random or organized way, inside areas with a lower variability (decorrelation of $15 \mathrm{~km}$ and $15 \mathrm{~min}$ ).

Jensen and Pedersen (2005) presented a study about variability in accumulated rainfall within a single radar pixel of $500 \mathrm{~m} \times 500 \mathrm{~m}$, comparing it with 9 rain gauges located in the same area. The results showed a variation of up to $100 \%$ at a maximum distance of about $150 \mathrm{~m}$, due to the rainfall spatial variability. This study suggested that a huge quantity of rain gauges is needed to have a powerful rain gauge network capable of representing small-scale variability. An alternative solution is to consider the variance reduction factor method, a numerical method to represent the uncertainty from averaging a number of rain gauges per pixel, taking into account their spatial distribution and the correlation between them. The variance reduction factor method was introduced for the first time by Rodriguez-Iturbe and Mej1a (1974) and lately applied in various studies (Krajewski et al., 2000; Villarini et al., 2008; Peleg et al., 2013).

Gires et al. (2014) focused on the gap between rain gauges and radar spatial scale, considering that a rain gauge usually collects rainfall over $20 \mathrm{~cm}$ of surface and the spatial resolution of most used radars is of $1 \mathrm{~km} \times 1 \mathrm{~km}$. They evaluate the impact of small-scale rainfall variability using a universal multifractal downscaling method. The downscaling process was validated with a dense rain gauge and disdrometer network, with 16 instruments located in $1 \mathrm{~km} \times 1 \mathrm{~km}$. They showed two effects of small-scale rainfall variability that are often not taken into account; high rainfall variability occurred below $1 \mathrm{~km}^{2}$ spatial scale and the random position of the point measurement within a pixel influenced measured rainfall events. Similar results are confirmed by Peleg et al. (2016), who studied the spatial variability of extreme rainfall at radar subpixel scale. Comparing a radar pixel of $1 \mathrm{~km} \times 1 \mathrm{~km}$ with high-resolution rainfall data, obtained by applying the stochastic rainfall generator STREAP (Paschalis et al., 2013) to simulate rain fields, this study highlights that subpixel variability is high and increases with increasing of return period and with shorter duration.

In Table 3 four types of rainfall events are presented with their characterization and typical spatial and temporal decor- 
Table 3. Characterization of rainfall events, spatial and temporal scales, and rainfall estimation uncertainty. From van de Beek et al. (2010), Smith et al. (1994), and Emmanuel et al. (2012).

\begin{tabular}{lllll}
\hline & $\begin{array}{l}\text { Characterization } \\
\text { and Intensity }\end{array}$ & $\begin{array}{l}\text { Spatial } \\
\text { Range }\end{array}$ & $\begin{array}{l}\text { Temporal } \\
\text { Range }\end{array}$ & $\begin{array}{l}\text { Radar } \\
\text { Estimation }\end{array}$ \\
\hline $\begin{array}{l}\text { Light } \\
\text { rainfall }\end{array}$ & $1 \mathrm{~mm} \mathrm{~h}^{-1}$ & $17 \mathrm{~km}$ & $15 \mathrm{~min}$ & $\begin{array}{l}\text { Underestimation rainfall values often } \\
\text { below the threshold }\left(0.17 \mathrm{~mm} \mathrm{~h}^{-1}\right)\end{array}$ \\
\hline $\begin{array}{l}\text { Convective } \\
\text { cells }\end{array}$ & $\begin{array}{l}\text { short and intense } \\
\text { from } 25 \mathrm{~mm}\end{array}$ & $5 \mathrm{~km}$ & $5 \mathrm{~min}$ & \begin{tabular}{l} 
Overestimation \\
\hline $\begin{array}{l}\text { Organized } \\
\text { stratiform }\end{array}$
\end{tabular} \\
$\begin{array}{llll}\text { up to } 17 \mathrm{~mm} \mathrm{~h}^{-1} \\
\begin{array}{l}\text { Unorganized } \\
\text { stratiform }\end{array}\end{array}$ & $\begin{array}{l}\text { high-intensity core, combined } \\
\text { with low-intensity areas }\end{array}$ & $15 \mathrm{~km}$ & $15 \mathrm{~min}$ & $\begin{array}{l}\text { Underestimation of the peaks, good } \\
\text { representation of the hyetograph behaviour }\end{array}$ \\
\hline
\end{tabular}

relation lengths, based on van de Beek et al. (2010), Emmanuel et al. (2012), and Smith et al. (1994). Considering that the minimal rainfall measurement resolution required for urban hydrological modelling is 0.4 the decorrelation length (Julien and Moglen, 1990; Berne et al., 2004; OchoaRodriguez et al., 2015b), operational radars are not able to satisfy this requirement.

\section{Hydrological processes}

In this section, general characteristics and parametrizations of hydrological processes are presented, highlighting their spatial and temporal variability and characteristics specific to urban environments.

\subsection{Precipitation losses}

\subsubsection{Infiltration, interception and storage}

The term infiltration is usually used to describe the physical processes by which rain enters the soil (Horton, 1933). Different equations and models have been proposed to describe infiltration. The most commonly used is Richards equation (Richards, 1931), which represents this phenomenon using a partial differential equation with non-linear coefficients.

Another possibility to estimate the infiltration capacity is given by the empirical equation presented by Horton (1939). In Horton's equation hydraulic conductivity and diffusivity are constant and do not depend on water content or on depth.

If water cannot infiltrate, as is the case in impervious areas, it can be stored in local depressions, where it does not contribute to runoff flow. This is the case of local depressions on streets or flat roofs, where water accumulates until the storage capacity is reached. Before reaching the ground, rainfall can be intercepted by vegetation cover or buildings. Interception can constitute up to $20 \%$ of rainfall at the start of a rainfall event (Mansell, 2003), and decreases quickly to zero, once surfaces are wetted.
During the process of transformation of rainfall in runoff, part of the water is lost due to several phenomena, such as infiltration, storage or evaporation. Ragab et al. (2003) presented an experimental study of water fluxes in a residential area, in which they estimated infiltration and evaporation in urban areas, showing that the assumption that all rainfall becomes runoff is not correct and that it leads to an overestimation of runoff. Ramier et al. (2011) studied the hydrological behaviour of urban streets over a 38-month period to estimate runoff losses and to better define rainfall runoff transformations. They estimated losses due to evaporation and infiltration inside the road structure between 30 and $40 \%$ of the total rainfall.

Spatial scale of precipitation losses is strongly influenced by land cover variation. In urban areas, land cover variability typically occurs at a spatial scale of 100 to $1000 \mathrm{~m}$. Timescale is associated with local storage accumulation volume, sorptivity, and hydraulic conductivity, which in turn depend on soil type and soil compaction.

\subsubsection{Groundwater recharge and subsurface processes in urban areas}

Groundwater recharge mechanisms change due to human activities and urbanization, both in terms of volume and quality of the water. The increase of imperviousness of land cover leads to a decrease in infiltration of rainfall into soil, reducing direct recharge to groundwater. The presence of leakage from drinking water and sewer networks can increase infiltration to groundwater and amount of contaminants that is spread from the sewer system into the soil (Salvadore et al., 2015).

Although it is well known that not all rainfall turns into runoff (Boogaard et al., 2013; Lucke et al., 2014), it is common to consider the losses from impervious areas so small that they can be assumed negligible compared to the total runoff volume (Ragab et al., 2003; Ramier et al., 2011). Ragab et al. (2003) tried to emphasize the importance of ac- 
counting for infiltration in the urban water balance, and found that infiltration through the road surface can constitute between 6 and $9 \%$ of annual rainfall. Due to high spatial variability of infiltration, representative measurements are difficult to obtain and require a large amount of point-scale measurements (Boogaard et al., 2013; Lucke et al., 2014).

Several types of pervious pavements are used in urban areas. They can generally be divided into monolithic and modular structures. Monolithic structures consist of a combination of impermeable blocks of concrete and open joints or apertures that allow water to infiltrate. In modular structures, gaps between two blocks are not filled with sand, as with conventional pavements, but with $2-5 \mathrm{~mm}$ of bedding aggregate, that facilitate infiltration (Boogaard et al., 2013). Following European standards, minimum infiltration capacity for permeable pavements is $270 \mathrm{~L} \mathrm{~s}^{-1} \mathrm{ha}^{-1}$, equal to $97.2 \mathrm{~mm} \mathrm{~h}^{-1}$ (Opzoekingscentrum voor de Wegenbouw, 2008).

Pervious areas in cities can effectively act as semiimpervious areas, because within the soil column there is a shallow layer that presents a low hydraulic conductivity at saturation, caused by soil compaction during the building process. Smith et al. (2015) studied the influence of this phenomenon on peak runoff flow by applying 21 storm events on a physically based, minimally calibrated model of the dead run urban area (USA) with and without the compacted soil layer. Results showed that the compacted soil layer reduced infiltration by $70-90 \%$ and increased peak discharge by $6.8 \%$.

\subsection{Surface runoff}

When rainfall intensity exceeds infiltration capacity of the soil, water starts to accumulate on the surface and flows following the slope of the ground. This process is generally called Hortonian runoff (Horton, 1933) or infiltration capacity excess flow. It is usually contrasted with saturation excess flow, or Dunne flow (Dunne, 1978), that occurs when the soil is saturated and rainfall can no longer be stored (van de Giesen et al., 2011).

In urban areas, runoff is generated when the surface is impervious and water can not infiltrate, or when infiltration capacity is exceeded by rainfall intensity. Water flows over the surface and can reach natural drainage channels or be intercepted by the drainage network through gullies and manholes. If the drainage network capacity is exceeded, the system become pressurized, and water starts to flow out from gullies, increasing runoff on the street (Ochoa-Rodriguez et al., 2015a).

It is important to pay attention to some elements that characterize the runoff in urban environments: sharp corners or obstacles can, for example, deviate the flow and introduce additional hydraulic losses. Interactions between surface flow and subsurface sewer systems through sewer inlets and gully pots are hydraulically complex and their influence on overland and in sewer flows remains poorly understood. Runoff flows are often characterized by very small water depths that are often alternated with dry surfaces, especially when rainfall intensities vary strongly in space and time.

\subsection{Impact of land cover on overland flow in urban areas}

In urban areas, the land cover, represented by an alternation of impervious surfaces, such as roads and roofs, and small pervious areas, such as gardens, vegetation and parks, shows a high variability in space.

The impact of increase of imperviousness on hydrological response was studied by Cheng (2002), who analysed the effects of urban development in Wu-Tu (Taiwan's catchment) considering 28 rainfall events (1966-1997). Results showed that response peak increased by $27 \%$ and the time to peak decreased from 9.8 to $5.9 \mathrm{~h}$, due to an increase of imperviousness from 4.78 to $11.03 \%$.

In a similar study, Smith et al. (2002) analysed the effects of imperviousness on flood peak in the Charlotte metropolitan region (USA), analysing a 74-year discharge record. Results showed that different land covers were associated with large differences in timing and magnitude of flood peak, while there were not significant differences in the total runoff volume. Hortonian runoff was the dominant runoff mechanism. Antecedent soil moisture played an important role in this watershed, even in the most urbanized catchment.

The influence of antecedent soil moisture is, however, not always so evident. Smith et al. (2013) showed that in nine watersheds, located in the Baltimore metropolitan area, the antecedent soil moisture, defined as 5-day antecedent rainfall, seemed not to affect the hydrological response. Introduction of storm water management infrastructure played an important role in reducing flood peaks and increasing runoff ratios. Results showed that rainfall variability may have important effects on spatial and temporal variation in flood hazard in this area.

Analysing the effects of a moderate extreme and an extreme rainstorm on the same area presented by Smith et al. (2013), Ogden et al. (2011) highlighted the importance of changes in imperviousness on flood peaks. They found that for extreme rainfall event, imperviousness had a small impact on runoff volume and runoff generation efficiency.

\subsection{Evaporation}

Evaporation plays an important role in the hydrological cycle: in forested catchment around $60-95 \%$ of total annual rainfall evaporates or is absorbed by the vegetation (Fletcher et al., 2013). In an urban catchment, evaporation is drastically reduced (Oke, 2006; Fletcher et al., 2013; Salvadore et al., 2015). Evaporation is often neglected in analysis of fast and intense rainfall events (Cui and Li, 2006); the order of magnitude of evaporation is very small compared to the total amount of rainfall. Some studies have shown that 
evaporation is not always negligible in urban areas and can constitute up to $40 \%$ of the annual total losses (Grimmond and Oke, 1991; Salvadore et al., 2015).

In their experimental study, Ragab et al. (2003) showed that evaporation represents $21-24 \%$ of annual rainfall, with more evaporation taking place during summer than winter. It is particularly important to have measurements with high resolution because a coarse spatial description can hide heterogeneous land covers and consequently, heterogeneous evaporation losses (Salvadore et al., 2015).

Evaporation measurements in urban areas are one of the weak points of the water balance (van de Ven, 1990) and they present many problems and challenges (Oke, 2006). It is quite hard in fact to find a site, representative of the area, far enough from obstacles and not unduly shaded. Errors in estimation of annual evaporation in urban areas may still be higher than $20 \%$ (van de Ven, 1990).

Different techniques and approaches have been developed to measure and estimate the impact of evaporation, from the standard lysimeter to the use of remote sensing (Nouri et al., 2013), to the combined used of remote sensing and ground measurements (Hart et al., 2009). Different models to estimate evaporation in urban areas have been proposed (Marasco et al., 2015; Litvak et al., 2017). Litvak et al. (2017) estimated evaporation in the urban area of Los Angeles, as combination of empirical models of turfgrass evaporation and tree transpiration derived from in situ measurements. Evaporation from non-vegetated areas appears to be negligible compared with the vegetation, and turfgrass was responsible for $70 \%$ of evaporation from vegetated areas.

\subsection{Flow in sewer systems}

In urban areas, part of the surface runoff enters in the sewer system through gully inlets, depending on the capacity of these elements, on their maintenance (Leitão et al., 2016) and the sewer system itself.

Storm water flow in sewer systems is highly non-uniform and unsteady, it can be considered as one dimensional, assuming that depth and velocity vary only in the longitudinal direction of the channel. Flow in sewer pipes is usually free surface, but during intense rainfall events the system can become full and temporarily behave as a pressurized system, a phenomenon called surcharge. In particular conditions, as for example in flat catchments, inversion of the flow direction in pipes can occur during filling and emptying of the system. The most common form to model flow in sewer pipes is based on a one-dimensional form of the de Saint-Venant equations.

Sewer system density influences runoff generation (Ogden et al., 2011; Yang et al., 2016): a dense pipe network can, in fact, reduce the runoff generation, increasing the storage capacity of the system (Yang et al., 2016). Ogden et al. (2011) presented a study about the importance of drainage density on flood runoff in urban catchments. Defin- ing the drainage density as channel length per total catchment area, they studied the hydrological response of the same basin modelled with drainage density that varied from 0.4 to $3.9 \mathrm{~km} \mathrm{~km}^{-2}$. Results showed a significant increase in peak discharge and runoff volume for drainage density between 0.4 and $0.9 \mathrm{~km} \mathrm{~km}^{-2}$, while for values higher than $0.9 \mathrm{~km} \mathrm{~km}^{-2}$, effects were negligible. When the storage and transport capacity of a system is not sufficient to prevent flooding, detention basins are effective tools to reduce peak flows, and they can reduce the superficial runoff up to $11 \%$ (Smith et al., 2015).

Similarly, green roofs can significantly decrease and slow peak discharge and reduce runoff volume. Versini et al. (2014) presented a study on the impact of green roofs at urban scale using a distributed rainfall model. They showed that green roofs can reduce runoff generation in terms of peak discharge, depending on the rainfall event and initial conditions. The reduction can be up to $80 \%$ for small events, with an intensity lower than $6 \mathrm{~mm}$.

\section{Urban hydrological models}

Urban hydrological models were developed since the 1970s to better understand the behaviour of the components of the water cycle in urban areas (Zoppou, 2000). Since then, many models, with different characteristics, principles, and complexity have been built. These models are used for several purposes, such as to study and predict the effects of urbanization increase on the hydrological cycle, to support flood risk management, to ensure clean and fresh drinking water for the population, and to support improvement of waste water networks and treatments (see Zoppou, 2000; Fletcher et al., 2013 for a review). A good summary of the most used urban hydrological models has been recently proposed by Salvadore et al. (2015), where a table with the most used hydrological models is presented and discussed.

Hydrological models have shown to be useful to compensate partially for the lack of measurements (Salvadore et al., 2015), but all models present errors and uncertainties of different nature and magnitude (Rafieeinasab et al., 2015). In this chapter, different classifications and characterizations of hydrological models are presented.

\subsection{Urban hydrological model characterization}

Hydrological models can be characterized and classified in different ways. A first distinction can be made according to the representation of spatial variability of the catchment. A lumped model does not consider spatial variability of the input, and uses spatial averaging to represent catchment behaviour. In contrast, distributed models describe spatial variability, usually using a node-link structure to describe subcatchment components (Zoppou, 2000; Fletcher et al., 2013). The choice of a suitable model depends on many factors 
and it is generally related to the applications and final objective. For example Berne et al. (2004) suggested a guideline for choosing between lumped and distributed modelling considering the representative surface associated to a single rain gauge $S_{\mathrm{r}}$. This characteristic, defined in relation to the rainfall spatial resolution $r$ as $S_{\mathrm{r}}=\pi[r / 2]^{2}$, is compared with the surface area of a catchment $S$. If $S_{\mathrm{r}}>S$ or $S_{\mathrm{r}} \sim S$ a lumped modelling approach is suggested, while for $S_{\mathrm{r}}<S$, a distributed model is recommended, as well as collecting measurements at the subcatchment scale. Different sub-categories are presented to characterize model spatial variability. Distributed models can be divided into fully distributed and semi-distributed models. Fully distributed models present a detailed discretization of the surface, using a grid or a mesh of regular or irregular elements, and apply the rainfall input to each grid element, generating grid-point runoff. The flow can be estimated at any location within the basin and not only at the catchment outlet. This is, however, possible only if the rainfall is provided with an appropriate spatial resolution. Semi-distributed models are based on subcatchment units, through which rainfall is applied. Each subcatchment is modelled in a lumped way, with uniform characteristics and a unique discharge point (Pina et al., 2014). Salvadore et al. (2015) proposed a model classification based on spatial variability with five categories: lumped, semi-distributed, Hydrological response unit based (semidistributed with a specific way to define the subcatchment area), grid-based spatially distributed, and urban hydrological element based (mainly focused on the urban fluxes).

Another distinction is between conceptual and physically based (or process based) models, depending on whether the model is based on physical laws or not. Recently, Fatichi et al. (2016) presented an overview of the advantages and limitations of physically based models in hydrology. They defined a physically based hydrological model as "a set of process descriptions that are defined depending on the objectives". The downsides of using a physically based model are related to over-complexity and over-parametrization: conceptual models are much easier to manage and they are usually less affected by numerical instability. Physically based models usually require high computational power and time and a large number of parameters, but there are situations in which it is important to keep the complexity to better understand system mechanisms. They are also necessary to deal with system variability and allow one to include a stochastic component to represent uncertainty in parameter and input values (Del Giudice et al., 2015).

\subsection{Spatial and temporal variability in urban hydrological models}

Depending on their characteristics, models can be very sensitive to spatial and temporal rainfall variability or not be able to correctly reproduce effects of this variability. Spatial variability of land cover and soil characteristics is an im- portant element in hydrological models. Choosing between a lumped, semi-distributed, or fully distributed hydrological model leads to different representation of catchment characteristics and, consequently, to a different output (Meselhe et al., 2009; Salvadore et al., 2015; Pina et al., 2016).

A comparison between semi-distributed and fully distributed urban storm water models was made by Pina et al. (2016). Two small urban catchments, Cranbrook (London, UK) and the centre of Coimbra (Portugal), were modelled with a semi- and a fully distributed model. Flow and depth in the sewer system of the different models were compared with observations and, in general, semi-distributed models predicted sewer flow patterns and peak flows more accurately, while fully distributed models had a tendency to underestimate flows. This was mainly due to the presence smallscale surface depressions, building singularities or lack of knowledge about private pipe connections. Although fully distributed models are more realistic and able to better represent spatial variability of the land cover, they need a higher resolution and accuracy to define module connections. Calibration of detailed, distributed models remains a complex issue that is not yet well resolved. The authors suggested to use a semi-distributed model approach in cases of low data resolution and accuracy.

To study the hydrological response Aronica and Canarozzo (2000) presented the Urban Drainage Topological Model (UDTM), a model that represents subcatchments of a semi-distributed model with two conceptual linear elements: a reservoir and a channel. In a more recent study (Aronica et al., 2005), this model was compared to the Storm Water Management Model (EPA SWMM model; Rossman, 2010), that allows the user to choose different conceptual models to simulate runoff and sewer flow. Results showed that model structure and sensitivity to parameters influence the sensitivity to the rainfall input resolution.

\section{Interaction of spatial and temporal rainfall variability with hydrological response in urban basins}

Storm structure and motion play an important role in the variability of the hydrological response (Smith et al., 1994; Bacchi and Kottegoda, 1995; Ogden et al., 1995; Singh, 1997; Emmanuel et al., 2012; Nikolopoulos et al., 2014; Emmanuel et al., 2015), especially for small catchments (Faures et al., 1995; Fabry et al., 1994). The characterization and the influence of spatial and temporal rainfall variability on runoff response is still not well understood (Emmanuel et al., 2015).

Recent studies address the impact of rainfall variability, focusing on urban catchments (Berne et al., 2004; OchoaRodriguez et al., 2015b; Rafieeinasab et al., 2015; Yang et al., 2016). The main results and conclusions are presented in the following sections. It is discussed how basin characteristics impact the sensitivity of hydrological response to rainfall 
variability and how the interaction between spatial and temporal rainfall variability influences hydrological response.

\subsection{Interaction between rainfall resolution and urban hydrological processes}

Many studies highlight the importance of high-resolution rainfall data (Notaro et al., 2013; Emmanuel et al., 2012; Bruni et al., 2015) and how their use could improve runoff estimation, especially in an urban scenario, where drainage areas are small and spatial variability is high (Schilling, 1991; Schellart et al., 2011; Smith et al., 2013). These studies have shown how catchments act as filters in space and time for hydrological response to rainfall, delaying peaks and smoothing the intensity. However, the influence of spatial variability of rainfall on catchment response in urban areas is complex and remains an open research subject.

A theoretical study, conducted by Schilling (1991), emphasized the necessity to use rainfall data with a higher resolution for urban catchments compared to rural areas, and suggested to choose a minimum temporal resolution of $1-5 \mathrm{~min}$ and a spatial resolution of $1 \mathrm{~km}$. The effects of temporal and spatial rainfall variability below $5 \mathrm{~min}$ and $1 \mathrm{~km}$ scale were subsequently studied by Gires et al. (2012). They investigated the urban catchment of Cranbrook (London, UK), with the aim of quantifying uncertainty in urban runoff estimation associated with unmeasured small-scale rainfall variability. Rainfall data were obtained from the national C-band radar with a resolution of $1 \mathrm{~km}^{2}$ and $5 \mathrm{~min}$ and were downscaled with a multifractal process, to obtain a resolution 9-8 times higher in space and 4-1 in time. Uncertainty in simulated peak flow associated with small-scale rainfall variability was found to be significant, reaching 25 and $40 \%$ respectively for frontal and convective events.

To investigate the effects of spatial and climatological variability on urban hydrological response, Peleg et al. (2017) used a stochastic rainfall generator to obtain high-resolution spatially variable rainfall as input for a calibrated hydrodynamic model. They compared the contributions of climatological rainfall variability and spatial rainfall variability on peak flow variability, over a period of 30 years. They found that peak flow variability is mainly influenced by climatological rainfall, while the effects of spatial rainfall variability increase for longer return periods.

Required rainfall resolution for urban hydrological modelling strongly depends on the characteristics of the catchment. Several researchers have studied the sensitivity of urban hydrological response to different rainfall resolutions, highlighting correlations between rainfall resolution and catchment dimensions, such as drained area (Berne et al., 2004; Ochoa-Rodriguez et al., 2015b) or catchment scale length (Ogden and Julien, 1994; Chirico et al., 2001; Bruni et al., 2015).

\subsection{Influence of spatial and temporal rainfall variability in relation to catchment dimensions}

Drainage area dimensions influence hydrological response and their sensitivities to spatial and temporal rainfall resolution have recently been investigated.

Wright et al. (2014) presented a flood frequency analysis, based on stochastic storm transposition (Wright et al., 2013) coupled with high-resolution radar rainfall measurements, with the aim to examine the effects of rainfall time and length scale on the flood response. Rainfall data were used as input for a physics-based hydrological model representative of 4 urbanized subcatchemnts. This study showed that there is an interaction between rainfall and basin characteristics, such as drainage area and drainage system location, that strongly affects the runoff.

Berne et al. (2004) studied the hydrological response of six urban catchments located in the south-east of the French Mediterranean coast. Rainfall data and runoff measurements were collected using two X-band weather radars, one vertically pointing radar, and one radar performing vertical plane cuts of the atmosphere, with a spatial resolution of 7.5 and $250 \mathrm{~m}$ and a temporal resolution of $4 \mathrm{~s}$ and $1 \mathrm{~min}$ respectively. The minimum temporal resolution required $\Delta t$ was defined as $\Delta t=t_{\mathrm{c}} / 4$, where $t_{\mathrm{c}}$ is the characteristic time of a system and the value 4 depends on catchment properties (Schilling, 1991). By considering lag time $t_{\text {lag }}$ equal to the characteristic time $t_{\mathrm{c}}$, it was possible to write the minimum required temporal resolution as a function of surface area $S$, based on the relationship $t_{\text {lag }}=3 S^{0.3}: \Delta t=0.75 S^{0.3}$. Spatial resolution was studied considering rainfall data collected from the $\mathrm{X}$-band weather radar performing vertical plane cuts of the atmosphere, combined with measurements of rain gauges. Two spatial climatological variograms were built with a time resolution of $1 \mathrm{~min}$ (from radar) and $6 \mathrm{~min}$ (from a network of 25 rain gauges). Based on variogram analysis, it was possible to define the relation between range $r$ and time resolution $\Delta t$ as $(r=4.5 \sqrt{\Delta t})$. The minimum required spatial resolution $\Delta s$ was defined by the authors as $\Delta s=r / 3$, and it can also be expressed as a function of $\Delta t$ :

$\Delta s=1.5 \Delta t$.

In this way, both spatial and temporal resolution requirements were defined as a function of surface dimensions of a catchment. Required resolutions for urban catchments of 100 ha are $3 \mathrm{~min}$ and $2 \mathrm{~km}$, but common operational rain gauge networks are usually less dense, while radars seldom provide data at this temporal resolution. Results presented are valid for catchments with characteristics similar to the catchments studied, such as surface area (from 10 to $10000 \mathrm{ha}$ ), slope (1 to $10 \%$ ), imperviousness degree (10 to $60 \%$ ), and exposed to climatic conditions similar to those of Mediterranean area.

Ochoa-Rodriguez et al. (2015b) analysed the impact of spatial and temporal rainfall resolution on hydrological re- 
sponse in seven urban catchments, located in areas with different geomorphological characteristics. Using rainfall data measured by a dual polarimetric X-band weather radar with spatial resolution of $100 \mathrm{~m} \times 100 \mathrm{~m}$ and temporal resolution of $1 \mathrm{~min}$, they investigated the effects of combinations of different resolutions, with the aim to identify critical rainfall resolutions. They investigated the impact of 16 combinations of 4 different spatial resolutions $(100 \mathrm{~m} \times 100 \mathrm{~m}, 500 \mathrm{~m} \times$ $500 \mathrm{~m}, 1000 \mathrm{~m} \times 1000 \mathrm{~m}$, and $3000 \mathrm{~m} \times 3000 \mathrm{~m}$ ) combined with four different temporal resolutions (1, 3, 5, and $10 \mathrm{~min})$. Resolution combinations were chosen considering different aspects, such as the operational resolution of radar and rain gauges networks, characteristics temporal and spatial scale. A strong relation between drainage area and critical rainfall resolution and between spatial and temporal resolutions was found. Sensitivity to different rainfall resolutions decreased when the size of the subcatchment considered increased, especially for catchment size above $1 \mathrm{~km}^{2}$. This study highlighted the importance of high-resolution rainfall data as input. Spatial resolution of $3 \mathrm{~km} \times 3 \mathrm{~km}$ is not adequate for urban catchments and temporal resolution should be lower than $5 \mathrm{~min}$. Most operational radars present a temporal resolution of $5 \mathrm{~min}$, not sufficient to correctly represent the effects of temporal rainfall variability.

The sensitivity to rainfall variability on 5 urban catchments of different sizes, located in the City of Arlington and Grand Prairie (USA), was studied with a distributed hydrological model (HLRDHM, Hydrology Laboratory Research Distributed Hydrological Model) by Rafieeinasab et al. (2015). Rainfall data were provided by the Collaborative Adaptive Sensing Atmosphere (CASA) X-band radar with spatial resolution of $250 \mathrm{~m} \times 250 \mathrm{~m}$ and temporal resolution of $1 \mathrm{~min}$ and upscaled in various steps to $2 \mathrm{~km} \times 2 \mathrm{~km}$ and $1 \mathrm{~h}$. Results showed peak intensity and time to peak error to be sensitive to spatial rainfall variability. The model was able to represent observed variability for all catchments except the smallest $\left(3.4 \mathrm{~km}^{2}\right)$ at a temporal resolution of $15 \mathrm{~min}$ or lower, combined with spatial variability of $250 \mathrm{~km} \times 250 \mathrm{~m}$ and capture variability in streamflow.

Resolution required to measure rainfall for small basins is usually high, as in the case of urban catchments. The influence of slope, imperviousness degree or soil type were not separately investigated, but the relationships between catchment area and rainfall resolution are expected to depend on these characteristics as well.

Sensitivity of hydrological response to different spatial and temporal rainfall resolutions has been investigated with dimensionless parameters to represent the length scales of storm events, catchments and of sewer networks.

Ogden and Julien (1994) identified dimensionless parameters to analyse correlations between catchment and storm characteristics and to study sensitivity of runoff models to radar-rainfall resolution. Rainfall data of a convective storm event, measured by a polarimetric radar with a spatial resolution of $1 \mathrm{~km} \times 1 \mathrm{~km}$, were applied on two basins. The storm smearing was defined as the ratio between rainfall data grid size and rainfall decorrelation length. Storm smearing occurs when rainfall data length is equal to or longer than the rainfall decorrelation length. The watershed smearing was described as the ratio between rainfall data grid size and basin length scale. When infiltration is negligible, watershed smearing is an important source of hydrological modelling errors, if the watershed ratio (rainfall measurement length/basin length) is higher than 0.4.

A similar approach, with dimensionless parameters, was recently applied by Bruni et al. (2015) to urban catchments. Rainfall data from a X-band dual polarimetric weather radar were applied to an hydrodynamic model, to investigate sensitivity of urban model outputs to different rainfall resolutions. The runoff sampling number was defined as ratio between rainfall length and runoff area length. Results confirm what was found by Ogden and Julien (1994). A third dimensionless parameter, called runoff sampling number, was identified. Small-scale rainfall variability at the $100 \mathrm{~m} \times 100 \mathrm{~m}$ affects hydrological response and the effect of spatial resolution coarsening on rainfall values strongly depends on the movement of storm cells relative to the catchment.

Using dimensionless parameters is a productive approach to study sensitivity of hydrological response to spatial and temporal rainfall variability. Effects of other catchment characteristics, such as slope or imperviousness, were so far neglected, but they need a deeper investigation.

\subsection{Spatial vs. temporal resolution}

As it was already discussed in previous sections, there is a dependency between spatial and temporal rainfall required resolution and they affect in a different way the hydrological response (Marsan et al., 1996; Singh, 1997; Berne et al., 2004; Gires et al., 2011; Ochoa-Rodriguez et al., 2015b).

A first interaction between spatial and temporal rainfall scale was defined based on the assumption that atmospheric properties are valid also for rainfall. Following this assumption, Kolgomorov's theory (Kolgomorov, 1962) was combined with the scaling properties of the Navier-Stokes equation, in order to define a relation between space and time variability. For large Reynolds numbers, in fact, the Navier-Stokes equation is invariant under scale transformations (Marsan et al., 1996; Deidda, 2000; Gires et al., 2011), and in this way temporal and spatial "scale changing" operator can be defined by dividing space and time ( $s$ and $t$ ) by scaling factors $\lambda_{s}$ and $\lambda_{t}$ relatively: $s \longmapsto s / \lambda_{s}$ and $t \longmapsto t / \lambda_{t}$. For scaling processes, there is a relation between scaling factors in time and space to take into account, that is represented the anisotropy coefficient $H_{t}: \lambda_{t}=\lambda_{s}^{\left(1-H_{t}\right)}$. $H_{t}$ is a priori unknown for rainfall, but it can be assumed equal to $1 / 3$, a value that characterize atmospheric turbulence (Marsan et al., 1996; Gires et al., 2011, 2012). Lovejoy and Schertzer (1991) estimated $H_{t}=0.5 \pm 0.3$ for raindrops. An example of application of this theory in a rainfall 
downscaling process is given by Gires et al. (2012): here, the rainfall is measured with a certain spatial resolution $s$ and temporal resolution $t$. They hypothesized to downscale the radar pixels, dividing the length by a scaling factor $\lambda_{s}=3$, to obtain nine pixels out of one. In this case, to keep the relation between spatial and temporal resolution, the duration of the time step has to be divided by a scaling factor $\lambda_{t}=\lambda_{s}^{1-1 / 3}=2^{2 / 3} \simeq 2$.

Studying the hydrological response of the south-east French Mediterranean coast, Berne et al. (2004) proposed another relationship between spatial $\Delta s$ and temporal $\Delta t$ resolution used to measure rainfall, as $\Delta s=1.5 \sqrt{\Delta t}$ (see Sect. 6.2 for the formula derivation).

Ochoa-Rodriguez et al. (2015b) derived the theoretically required spatial rainfall resolution for urban hydrological modelling starting from a climatological variogram, which characterized average spatial structure of rainfall fields over the peak storm period, fitted with an exponential variogram model. They defined characteristic length scale $r_{\mathrm{c}}$ of a storm event as $r_{\mathrm{c}}=(\sqrt{2 \pi} / 3) r$, where $r$ is the variogram range. The minimum required spatial resolution for adequate modelling of urban hydrological response was defined as half characteristic length scale of the storm: $\Delta s=r_{\mathrm{c}} / 2 \cong 0.418 r$. The theoretically required temporal resolution $\Delta t$, was defined based on the time needed for a storm to move over distance equal to the characteristic length scale of the storm event $r_{\mathrm{c}}$. It can be written as $\Delta t=r_{\mathrm{c}} / v$, where $v$ is the magnitude of the mean storm velocity, obtained from average of the velocity vectors (magnitude and direction) estimated at each time step. Ochoa-Rodriguez et al. (2015b)investigated also the impact of different combinations of spatial and temporal resolutions as described in Sect. 6.2. One of the criteria used to choose some of the resolution combination was the already discussed in the literature (Berne et al., 2004), and according to Kolgomorov's scaling theory (Kolgomorov, 1962). Results showed that hydrodynamic models are more sensitive to the coarsening of temporal resolution of rainfall inputs than to the coarsening of spatial resolution, especially for fast moving storms.

In this work, the authors presented also a relation between spatial and temporal critical rainfall resolutions depending on drainage area (Table 4). For small catchments, with area smaller than $1 \mathrm{ha}$, was found to be equal to $100 \mathrm{~m} \times 100 \mathrm{~m}$ and $1 \mathrm{~min}$, while for areas between 1 and $100 \mathrm{ha}$, a spatial resolution of $500 \mathrm{~m} \times 500 \mathrm{~m}$ can be sufficient to estimate the hydrological response. The critical spatial resolution found is lower than $5 \mathrm{~min}$, for catchment size from about 250 to 900 ha. Results were confirmed by Yang et al. (2016), that presented an analysis of flash flooding in two small urban subcatchments of Harry's Brook (Princeton, New Jersey, USA), focusing on the influence of rainfall variability of storm events on hydrological response.
Table 4. Critical resolutions in relation with the drainage area.

\begin{tabular}{lrr}
\hline $\begin{array}{l}\text { Drainage Area } \\
\text { DA } \\
\text { (ha) }\end{array}$ & $\begin{array}{r}\text { Critical spatial } \\
\text { resolution } \\
(\mathrm{m} \times \mathrm{m})\end{array}$ & $\begin{array}{r}\text { Critical temporal } \\
\text { resolution } \\
(\mathrm{min})\end{array}$ \\
\hline $\mathrm{DA}<1$ & 100 & 1 \\
$1<\mathrm{DA}<100$ & 500 & 1 \\
$250<\mathrm{DA}<900$ & 1000 & $<5$ \\
\hline
\end{tabular}

Spatial variability seems to influence timing of runoff hydrograph, while temporal variability mainly influences peak value Singh (1997).

Ochoa-Rodriguez et al. (2015b) investigated the influence of spatial and temporal scaling factor introduced at the beginning of this section, on runoff estimation from different input, introducing also a combined spatio-temporal factor $\Theta_{s t}$. This factor was defined using the anisotropy coefficient as $\Theta_{s t}=\left(\frac{\Delta S_{\mathrm{r}}}{\Delta S}\right)\left(\frac{\Delta t}{\Delta t_{\mathrm{r}}}\right)^{\left(\frac{1}{1-H_{t}}\right)}$, where $\Delta S$ and $\Delta t_{\mathrm{r}}$ are the required spatial and temporal resolutions, $\Delta S$ and $\Delta t$ are the space and time resolutions used as input for model simulations and $H_{t}$ is the scaling anisotropy factor. The stronger relation between drainage area and combined spatio-temporal factor $\Theta_{s t}$ compared to the relation with singular spatial or temporal scaling factor suggests that the effects of space and time has to be considered together. However, the combined effects of spatial and temporal resolution on the sensitivity to hydrological response requires future works and deeper investigations.

These studies highlighted the relatively more important role of temporal variability compared to spatial variability, for extreme rainfall events. The impact of the spatial variability, seemed to decrease with increase of total rainfall accumulation.

\section{$7 \quad$ Summary and future directions}

In this article, the state of the art of spatial and temporal variability impacts of rainfall and catchment characteristics on hydrological response in urban areas has been presented. The main key points and conclusion of this study are the following.

A first aspect that has been highlighted is the high variability in space and time of hydrological processes and phenomena in urban environments. Measuring, understanding and effectively characterizing temporal and spatial variability at small-scales is therefore of utmost importance. Highresolution data are essential given the high variability of catchment characteristics and hydrological processes, such as infiltration, evaporation and surface runoff. An important role in urban areas is played by drainage infrastructures that highly affect the hydrological response, while in some cases the effects of these structures are not perfectly understood. Current methods and instruments often have insufficient ca- 
pability to measure the considered process at their relevant scales.

Several definitions to classify timescale characteristics are available in the literature, such as time of concentration, lag time, time of equilibrium and response timescale. However, measurement or estimation of those parameters is often ambiguous, which implies a high level of uncertainty. Thus far, no common agreement has emerged on a unique set of parameters able to characterize small-scale variability of urban catchments in a way that enhances our understanding of urban hydrological response. Improved rainfall measurements have also allowed to investigate the relations between temporal and spatial rainfall scale. Relations have been presented, mostly adapting the Kolgomorov?s theory to rainfall, to define the interaction between spatial and temporal scale in atmosphere. A unique relationship has not yet been found. This highlights the need for methods that can better characterize spatial and temporal scale parameters of rainfall and urban catchments in an effective way.

Uncertainty associated with rainfall spatial and temporal variability is one of the main sources of error in the estimation of hydrological response in urban areas. New technologies have been developed to measure rainfall spatial and temporal variability more accurately and at higher resolution. While rain gauges remain the most common used rainfall measurement instruments, weather radars are a promising example of recently developed instruments, able to estimate rainfall variability at high resolution. However, they still need to be combined with rain gauge networks in order to improve their accuracy. Rain gauges applied in urban areas present many limitations due to strong microclimatic variability, complicating identification of suitable locations for representative rainfall measurements. Polarimetric X-band radars combine high-resolution and high-accuracy measurement capability with the advantages of local installation thus avoiding overshooting and resolution loss with distance associated with large radar network. They constitute a promising direction for future urban hydrological research and rainfall and flood forecasting applications.

Many studies are reported in the literature using hydrological models with different characteristics and different representations of the catchment spatial variability. Different types of hydrological models have been developed in order to represent the spatial variability of catchment properties, such as land cover and imperviousness degree. Models can be classified based on their ability to represent the spatial variability of the catchment into lumped, semi-distributed and fully distributed models. These models have become more and more detailed, reaching high levels of spatial resolution. However, unless they are driven by similarly high-resolution rainfall data, increasing model resolution cannot fundamentally improve understanding of hydrological processes or improve reliability of hydrological predictions. Infiltration, local storage, interception and evaporation are quite difficult to mea- sure, especially in urban areas, because of the strong heterogeneity of urban land use.

The impact of spatial and temporal rainfall variability on the hydrological response in urban areas and the role of drainage infrastructure and man-made control structures herein still remains poorly understood. It was found that sensitivity of hydrological response to spatial and temporal rainfall variability varies with catchment size, catchment shape, storm scale and storm velocity. So far, findings are mainly based on sensitivity studies using theoretical model scenarios. A wider range of conditions and scenarios based on observational datasets for urban hydrological basins need to be analysed in order to characterize better the hydrological response and its sensitivity to different spatial and temporal rainfall resolutions.

Data availability. No data sets were used in this article.

Competing interests. The authors declare that they have no conflict of interest.

Special issue statement. This article is part of the special issue "Rainfall and urban hydrology".

Acknowledgements. This work has been supported by the EU INTERREG IVB through funding of the RainGain Project (http://www.raingain.eu).

Edited by: Peter Molnar

Reviewed by: two anonymous referees

\section{References}

Aronica, G. and Canarozzo, M.: Studying the hydrological response of urban catchments using a semi-distributed linear non-linear model, J. Hydrol., 238, 35-43, 2000.

Aronica, G., Freni, G., and Oliveri, E.: Uncertainty analysis of the influence of rainfall time resolution in the modelling of urban drainage systems, Hydrol. Process., 19, 1055-1071, 2005.

Bacchi, B. and Kottegoda, N.: Identification and calibration of spatial correlation patterns of rainfall, J. Hydrol., 165, 311-348, 1995.

Bergstrom, S. and Graham, L. P.: On the scale problem in hydrological modelling, J. Hydrol., 211, 253-265, 1998.

Berndtsson, R. and Niemczynowicz, J.: Spatial and temporal scales in rainfall analysis - some aspects and future perspective, J. Hydrol., 100, 293-313, 1986.

Berne, A. and Krajewski, W.: Radar for hydrology: Unfulfilled promise or unrecognized potential?, Adv. Water Resour., 51, 357-366, 2013. 
Berne, A., Delrieu, G., Creutin, J., and Obled, C.: Temporal and spatial resolution of rainfall measurements required for urban hydrology, J. Hydrol., 299, 166-179, 2004.

Blöschl, G. and Sivapalan, M.: Scale issues in hydrological modelling: a review, Hydrol. Process., 9, 251-290, 1995.

Boogaard, F., Lucke, T., and Beecham, S.: Effect of Age of Permeable Pavements on Their Infiltration Function, Clean Soil Air Waters, 41, 146-152, 2013.

Bruni, G., Reinoso, R., van de Giesen, N. C., Clemens, F. H. L. R., and ten Veldhuis, J. A. E.: On the sensitivity of urban hydrodynamic modelling to rainfall spatial and temporal resolution, Hydrol. Earth Syst. Sci., 19, 691-709, https://doi.org/10.5194/hess19-691-2015, 2015.

Cheng, S.and Wang, R.: An approach for evaluating the hydrological effects of urbanization and its application, Hydrol. Process., 16, 1403-1418, 2002.

Chirico, G. B., Grayson, R. B., Western, A. W., Woods, R., and Seed, A.: Sensitivity of simulated catchment response to the spatial resolution of rainfall, Proceedings of conference: MODSIM 2001, Modelling and Simulation Society of Australia and New Zealand inc, 10-13 December 2001, Canberra, Australia, 377388, 2001

Ciach, G. J. and Krajewski, W. F.: On the estimation of radar rainfall error variance, Adv. Water Resour., 22, 585-595, https://doi.org/10.1016/s0309-1708(98)00043-8, 1999.

Cole, S. and Moore, R.: Hydrological modelling using rain gaugeand radar-based estimators of areal rainfall, J. Hydrol., 358, 159$181,2008$.

Cui, X. and Li, X.: Role of surface evaporation in surface rainfall processes, J. Geophys. Res., 111, D17112, https://doi.org/10.1029/2005JD006876, 2006.

Dai, Q., Rico-Ramirez, M. A., Han, D., Islam, T., and Liguori, S.: Probabilistic radar rainfall nowcast using empirical and theoretical uncertainty models, Hydrol. Process., 29, 66-79, 2015.

Daniels, E. E., Lenderink, G., Hutjes, R. W. A., and Holtslag, A. A. M.: Observed urban effects on precipitation along the Dutch West coast, Int. J. Climatol., 36, 2111-2119, https://doi.org/10.1002/joc.4458, 2015.

Deidda, R.: Rainfall downscaling in a space time multifractal framework, Water Resour. Res., 36, 1779-1794, 2000.

Del Giudice, D., Löwe, R., Madsen, H., Mikkelsen, P. S., and Rieckermann, J.: Comparison of two stochastic techniques for reliable urban runoff prediction by modeling systematic errors, Water Resour. Res., 51, 5004-5022, 2015.

Dunne, T.: Field studies of hillslope flow processes, in: Hillslope Hydrology, edited by: Kirkby, M. J., Wiley, New York, USA, 227-293, 1978.

Einfalt, T., Arnbjerg-Nielsen, K., Golz, C., Jensen, N., Quirmbach, M., Vaes, G., and Vieux, B.: Towards a Roadmap for Use of Radar Rainfall data use in Urban Drainage, J. Hydrol., 299, 186202, 2004.

Emmanuel, I., Andrieu, H., Leblois, E., and Flahaut, B.: Temporal and spatial variability of rainfall at the urban hydrological scale, J. Hydrol., 430-431, 162-172, 2012.

Emmanuel, I., Andrieu, H., Leblois, E., Janey, N., and Payrastre, O.: Influence of rainfall spatial variability on rainfall-runoff modelling: benefit of a simulation approach?, J. Hydrol., 531, 337$348,2015$.
Fabry, F., Bellon, A., Duncan, M. R., and Austin, G. L.: High resolution rainfall measurements by radar for very small basins: the sampling problem reexamined, J. Hydrol., 161, 415-428, 1994.

Fatichi, S., Vivoni, E. R., Ogden, F. L., Ivanov, V. Y., Mirus, B., Gochis, D., Downer, C. W., Camporese, M., Davison, J. H., and Ebel, B. E. A.: An overview of current applications,challenges, and future trends in distributed process-based models in hydrology, J. Hydrol., 537, 45-60, 2016.

Faures, J., Goodrich, D. C., Woolhiser, D. A., and Sorooshian, S.: Impact of small scale spatial rainfall variability on runoff modelling, J. Hydrol., 173, 309-326, 1995.

Fencl, M., Rieckermann, J., Sýkora, P., Stránský, D., and Bareš, V.: Commercial microwave links instead of rain gauges: fiction or reality?, Water Sci. Technol., 71, 31-37, https://doi.org/10.2166/wst.2014.466, 2015.

Fencl, M., Dohnal, M., Rieckermann, J., and Bareš, V.: Gauge-adjusted rainfall estimates from commercial microwave links, Hydrol. Earth Syst. Sci., 21, 617-634, https://doi.org/10.5194/hess-21-617-2017, 2017.

Ferraris, L., Gabellani, S., Rebora, N., and Provenzale, A.: A comparison of stochastic models for spatial rainfall downscaling, Water Resour. Res., 39, 1368, https://doi.org/10.1029/2003WR002504, 2003.

Fletcher, T. D., Andrieu, H., and Hamel, P.: Understanding, management and modelling of urban hydrology and its consequences for receiving waters: a state of the art, Adv. Water Resour., 51, 261-279, 2013.

Fonstad, M. A., Dietrich, J. T., Courville, B. C., Jensen, J. L., and Carbonneau, P. E.: Topographic structure from motion: a new development in photogrammetric measurement, Earth Surf. Proc. Land., 38, 421-430, 2013.

Foresti, L., Reyniers, M., Seed, A., and Delobbe, L.: Development and verification of a real-time stochastic precipitation nowcasting system for urban hydrology in Belgium, Hydrol. Earth Syst. Sci., 20, 505-527, https://doi.org/10.5194/hess-20-505-2016, 2016.

Fowler, H. J., Blenkinsop, S., and Tebaldi, C.: Linking climate change modelling to impacts studies: recent advances in downscaling techniques for hydrological modelling, Int. J. Climatol., 27, 1547-1578, https://doi.org/10.1002/joc.1556, 2007.

Gericke, O. J. and Smithers, J. C.: Review of methods used to estimate catchment response time for the purpose of peak discharge estimation, Hydrolog. Sci. J., 59, 1935-1971, 2014.

Gires, A., Onof, C., Tchiguirinskaia, I., Schertzer, D., and Lovejoy, S.: Analyses multifractales et spatio-temporelles des précipitations du modèle Méso-NH et des données radar, Hydrolog. Sci. J., 56, 380-396, 2011.

Gires, A., Onof, C., Maksimovic, C., Schertzer, D., Tchiguirinskaia, I., and Simoes, N.: Quantifying the impact of small scale unmeasured rainfall variability on urban hydrology through multifractal downscaling: a case study, J. Hydrol., 442-443, 117-128, 2012.

Gires, A., Tchiguirinskaia, I., Schertzer, D., Schellart, A., Berne, A., and Lovejoy, S.: Influence of small scale rainfall variability on standard comparison tools between radar and rain gauge data, Atmos. Res., 138, 125-138, 2014.

Gironás, J., Niemann, J., Roesner, L., Rodriguez, F., and Andrieu, H.: Evaluation of Methods for Representing Urban Terrain in Storm-Water Modeling, J. Hydrol. Eng., 15, 1-14, 2010.

Givati, A. and Rosenfeld, D.: Quantifying precipitation suppression due to air pollution, J. Appl. Meteorol., 43, 1038-1056, 2004. 
Grimmond, C. and Oke, T.: An evapotranspiration-interception model for urban areas, Water Resour. Res., 27, 1739-1755, 1991.

Hart, Q. J., Brugnach, M., Temesgen, B., Rueda, C., Ustin, S. L., and Frame, K.: Daily reference evapotranspiration for California using satellite imagery and weather station measurement interpolation, Civ. Eng. Environ. Syst., 26, 19-33, https://doi.org/10.1080/10286600802003500, 2009.

Horton, R.: The role of infiltration in the hydrologic cycle, Eos Trans. AGU, 14, 446-460, 1933.

Horton, R.: Analysis of runoff-plat experiments with varing infiltration-capacity, EOS Earth and Space Science News, 20, 693-711, 1939.

Huff, F. A. and Changno, S. A. J.: Precipitation Modification By Major Urban Areas, B. Am. Meteorol. Soc., 54, 1220-1232, 1973.

Jensen, N. E. and Pedersen, L.: Spatial variability of rainfall: Variations within a single radar pixel, Atmos. Res., 77, 269-277, 2005.

Julien, P. Y. and Moglen, G. E.: Similarity and length scalefor spatially varied overland flow, Water Resour. Res., 26, 1819-1832, 1990.

Kolgomorov, A. N.: A refinement of previous hypotheses concerning the local structure of turbulence in a viscous incompressible fluid at high Reynolds number, J. Fluid Mech., 13, 82-85, 1962.

Krajewski, W. F. and Smith, J. A.: Radar hydrology: rainfall estimation, Adv. Water Resour., 25, 1387-1394, 2005.

Krajewski, W. F., Ciach, G. J., McCollum, J. R., and Bacotiu, C.: Initial validation of the global precipitation climatology project monthly rainfall over the United States, J. Appl. Meteorol., 39, 1071-1086, https://doi.org/10.1175/15200450(2000)039<1071:ivotgp>2.0.co;2, 2000.

Kuichling, E.: The Relation between the Rainfall and the Discharge of Sewers in Populous Districts, Transactions of ASCE, 20, 1$60,1889$.

Lanza, L. and Stagi, L.: High resolution performance of catching type rain gauges from the laboratory phase of the WMO Field Intercomparison of Rain Intensity Gauges, Atmos. Res., 94, 555$563,2009$.

Lanza, L. and Vuerich, E.: The WMO Field Intercomparison of Rain Intensity Gauges, Atmos. Res., 94, 534-543, 2009.

Larson, C. L.: A two phase approach to the prediction of peak rates and frequencies of runoff for small ungauged watersheds, Technical Report n. 53, Department of Civil Engineering, Standford University, Stanford, USA, 1965.

Leijnse, H., Uijlenhoet, R., and Stricker, J.: Rainfall measurement using radio links from cellular communication networks, Water Resour. Res., 43, W03201, https://doi.org/10.1029/2006WR005631, 2007.

Leitão, P. J., Simões, N. E., Pina, R. D., Ochoa-Rodriguez, S., Onof, C., and Marques, A. S.: Stochastic evaluation of the impact of sewer inlets' hydraulic capacity on urban pluvial flooding, Stoch. Environ. Res. Risk Assess., 1-16, https://doi.org/10.1007/s00477-016-1283-x, 2016.

Liguori, S. and Rico-Ramirez, M. A.: A review of current approaches to radar based Quantitative Precipitation Forecasts, International Journal of River Basin Management, 12, 391-402, 2013.

Litvak, E., Manago, K. F., Hogue, T. S., and Pataki, D. E.: Evapotranspiration of urban landscapes in Los Angeles, California at the municipal scale, Water Resour. Res., 53, 4236-4252, https://doi.org/10.1002/2016WR020254, 2017.

Lovejoy, S. and Schertzer, D.: Multifractal analysis techniques and the rain and cloud fields from $10^{-3}$ to $10^{6} \mathrm{~m}$, Non linear variability in geophysics, 111-144, https://doi.org/10.1007/978-94009-2147-4_8, 1991.

Lucke, T., Boogaard, F., and van de Ven, F.: Evaluation of a new experimental test procedure to more accurately determine the surface infiltration rate of permeable pavement systems, Urban, Planning and Transport Research: An Open Access Journal, 2, 22-35, 2014.

Mandapaka, P. V., Krajeski, W. F., Ciach, G. J., Villarini, G., and Smith, J. A.: Estimation of radar-rainfall error spatial correlation, Adv. Water Resour., 32, 1020-1030, 2009.

Mansell, M. G.: Rural and urban hydrology, Thomas Telford Ltd, London, UK, 2003.

Marasco, D. E., Culligan, P. J., and McGillis, W.: Evaluation of common evapotranspiration models based on measurements from two extensive green roofs in New York City, Ecol. Eng., 84, 451-462, https://doi.org/10.1016/j.ecoleng.2015.09.001, 2015.

Marchi, L., Borga, M., Preciso, E., and Gaume, E.: Characterisation of selected extreme flash floods in Europe and implications for flood risk management, Hydrol. Process., 23, 2714-2727, 2010.

Marsan, D., Schertzer, D., and Lovejoy, S.: Causal space-time multifractal processes: Predictability and forecasting of rain fields, J. Geophys. Res., 101, 26333-26346, 1996.

Marshall, J. S. and Palmer, W. M. K.: The distribution of raindrops with size, McGill University, https://doi.org/10.1175/15200469(1948)005<0165:TDORWS>2.0.CO;2, 1948.

Mayer, H.: Automatic Object Extraction from Aerial Imagery - A Survey Focusing on Buildings, Comput. Vis. Image Und., 74, 138-149, 1999.

McCuen, R. H., Wong, S. L., and Rawls, W. J.: Estimating Urban Time of Concentration, J. Hydraul. Eng., 110, 887-904, https://doi.org/10.1061/(ASCE)0733-9429(1984)110:7(887), 1984.

McRobie, F. H., Wang, L.-P., Onof, C., and Kenney, S.: A spatialtemporal rainfall generator for urban drainage design, Water Sci. Technol., 68, 240-249, https://doi.org/10.2166/wst.2013.241, 2013.

Meselhe, E., Habib, E., Oche, O., and Gautam, S.: Sensitivity of conceptual and physically based hydrologic models to temporal and spatial rainfall sampling, J. Hydrol. Eng., 14, 711-720, 2009.

Montanari, A. and Grossi, G.: Estimating the uncertainty of hydrological forecasts: A statistical approach, Water Resour. Res., 44, W00B08, https://doi.org/10.1029/2008WR006897, 2008.

Morin, E., Enzel, Y., Shamir, U., and Garti, R.: The characteristic time scale for basin hydrological response using radar data, J. Hydrol., 252, 85-99, 2001.

Morin, E., Georgakakos, K. P., Shamir, U., Garti, R., and Enzel, Y.: Objective, observations-based, automatic estimation of the catchment response timescale, Water Resour. Res., 38, 1212, https://doi.org/10.1029/2001WR000808, 2002.

Morin, E., Georgakakos, K. P., Shamir, U., Garti, R., and Enzel, Y.: Investigating the effect of catchment characteristics on the response time scale using a distributed model and weather radar information, Weather Radar Information and Distributed Hydrological Modelling, Proceedings of symposium I-IS03 held dur- 
ing IUOG2003 at Sapporo, Japan, 30 June-11 July 2003, IAHS Publ., 282, 177-185, 2003.

Musy, A. and Higy, C.: Hydrology A Science of Nature, Science Publishers, CRC Press, Boca Raton, Florida, USA, 2010.

Muthusamy, M., Schellart, A., Tait, S., and Heuvelink, G. B. M.: Geostatistical upscaling of rain gauge data to support uncertainty analysis of lumped urban hydrological models, Hydrol. Earth Syst. Sci., 21, 1077-1091, https://doi.org/10.5194/hess-21-10772017, 2017.

Nielsen, J. E., Thorndahl, S., and Rasmussen, M. R.: Improving weather radar precipitation estimates by combining two types of radars, Atmos. Res., 139, 36-45, https://doi.org/10.1016/j.atmosres.2013.12.013, 2014.

Niemczynowicz, J.: The rainfall movement - A valuable complement to short-term rainfall data, J. Hydrol., 104, 311-326, 1988.

Niemczynowicz, J.: Urban hydrology and water management present and future challenges, Urban Water, 1, 1-14, 1999.

Niemi, T. J., Guillaume, J. H. A., Kokkonen, T., Hoang, T. M. T., and Seed, A. W.: Role of spatial anisotropy in design storm generation: Experiment and interpretation, Water Resour. Res., 52, 69-89, https://doi.org/10.1002/2015WR017521, 2016.

Nikolopoulos, E., Borga, M., Zoccatelli, D., and Anagnostou, E. N.: Catchment scale storm velocity: quantification, scale dependence and effect on flood response, Hydrolog. Sci. J., 59, 1363-1376, 2014.

Notaro, V., Fontanazza, C. M., Freni, G., and Puleo, V.: Impact of rainfall data resolution in time and space on the urban flooding evaluation, Water Sci. Technol., 68, 1984-1993, 2013.

Nouri, H., Beecham, S., Kazemi, F., and Hassanli, A.: A review of ET measurement techniques for estimating the water requirements of urban landscape vegetation, Urban Water, 10, 247-259, 2013.

Ochoa-Rodriguez, S., Onof, C., Maksimovic, C., Wang, L., Willems, P., Assel, J., Gires, A., Ichiba, A., Bruni, G., and ten Veldhuis, A. E. J.: Urban pluvial flood modelling: current theory and practice. Review document related to Work Package 3, RainGain Project, WP3 review document, available at: http://www.raingain.eu (last access: 31 May 2017), 2015a.

Ochoa-Rodriguez, S., Wang, L., Gires, A., Pina, R., ReinosoRondinel, R., Bruni, G., Ichiba, A., Gaitan, S., Cristiano, E., Assel, J., Kroll, S., Murlà-Tuyls, D., Tisserand, B., Schertzer, D., Tchiguirinskaia, I., Onof, C., Willems, P., and ten Veldhuis, A. E. J.: Impact of Spatial and Temporal Resolution of Rainfall Inputs on Urban Hydrodynamic Modelling Outputs: A MultiCatchment Investigation, J. Hydrol., 531, 389-407, 2015b.

Ogden, F. L. and Dawdy, D. R.: Peak discharge scaling in small hortonian watershed, J. Hydrol. Eng., 8, 64-73, 2003.

Ogden, F. L. and Julien, P. Y.: Runoff model sensitivity to radar rainfall resolution, J. Hydrol., 158, 1-18, 1994.

Ogden, F. L., Richardson, J. R., and Julien, P. Y.: Similarity in catchment response, Water Resour. Res., 31, 1543-1547, 1995.

Ogden, F. L., Pradhan, N. R., Downer, C. W., and Zahner, J. A.: Relative Importance of Impervious Area, Drainage Density, width Function, and Subsurface Storm Drainage on Flood Runoff from an Urbanized Catchment, Water Resour. Res., 47, 1-12, 2011.

Oke, T. R.: Initial Guidance to Obtain Representative Meteorological Observations at Urban Sites, OM Report No.81, WMO/TD No. 1250, World Meteorological Organization, Geneva, Switzerland, 2006.
Opzoekingscentrum voor de Wegenbouw: Waterdoorlatende Verhardingen met Betonstraatstenen, Report on pervious pavements, Brussel, Belgium, 2008.

Otto, T. and Russchenberg, H. W.: Estimation of Specific Differential Phase Backscatter Phase From Polarimetric Weather Radar Measurement of Rain, IEEE Geosci. Remote S., 5, 988-922, 2011.

Overeem, A., Holleman, I., and Bruihand, A.: Derivation of a 10 year radar based climatology of rainfall, J. Appl. Meteorol. Clim., 48, 1448-1463, 2009a.

Overeem, A., Buishand, A., and Holleman, I.: Extreme rainfall analysis and estimation of depth duration frequency curves using weather radar, Water Resour. Res., 45, W10424, https://doi.org/10.1029/2009WR007869, 2009b.

Paschalis, A., Molnar, P., Fatichi, S., and Burlando, P.: A stochastic model for high resolution space-time precipitation simulation, Water Resour. Res., 49, 8400-8417, https://doi.org/10.1002/2013WR014437, 2013.

Peleg, N. and Morin, E.: Stochastic convective rain-field simulation using a high-resolution synoptically conditioned weather generator (HiReS-WG), Water Resour. Res., 50, 2124-2139, https://doi.org/10.1002/2013WR014836, 2014.

Peleg, N., Ben-Asher, M., and Morin, E.: Radar subpixel-scale rainfall variability and uncertainty: lessons learned from observations of a dense rain-gauge network, Hydrol. Earth Syst. Sci., 17, 2195-2208, https://doi.org/10.5194/hess-17-2195-2013, 2013.

Peleg, N., Marra, F., Fatichi, S., Paschalis, A., Molnar, P., and Burlando, P.: Spatial variability of extreme rainfall at radar subpixel scale, J. Hydrol., in press, https://doi.org/10.1016/j.jhydrol.2016.05.033, 2016.

Peleg, N., Blumensaat, F., Molnar, P., Fatichi, S., and Burlando, P.: Partitioning the impacts of spatial and climatological rainfall variability in urban drainage modeling, Hydrol. Earth Syst. Sci., 21, 1559-1572, https://doi.org/10.5194/hess-21-1559-2017, 2017.

Pina, R., Ochoa-Rodriguez, S., Simones, N.and Mijic, A., Sa Marques, A., and Maksimovik, C.: Semi-distributed or fully distributed rainfall-runoff models for urban pluvial flood modelling?, 13th International Conference on Urban Drainage, 712 September 2014, Sarawak, Malaysia, 2014.

Pina, R., Ochoa-Rodriguez, S., Simones, N., Mijic, A., Sa Marques, A., and Maksimovik, C.: Semi- vs fully- distributed urban stormwater models: model set up and comparison with two real case studies, Water, 8, 58, https://doi.org/10.3390/w8020058, 2016.

Quirmbach, M. and Schultz, G. A.: Comparison of rain gauge and radar data as input to an urban rainfall-runoff model, Water Sci. Technol., 45, 27-33, 2016.

Rafieeinasab, A., Norouzi, A., Kim, S., Habibi, H., Nazari, B., Seo, D., Lee, H., Cosgrove, B., and Cui, Z.: Toward high-resolution flash flood prediction in large urban areas - Analysis of sensitivity to spatiotemporal resolution of rainfall input and hydrologic modeling, J. Hydrol., 531, 370-388, 2015.

Ragab, R., Rosier, P., Dixon, A., Bromley, J., and Cooper, J. D.: Experimental study of water fluxes in a residential area: 2. Road infiltration, runoff and evaporation, Hydrol. Process., 17, 24232437, 2003.

Ramier, D., Berthier, E., and Andrieu, H.: The hydrological behaviour of urban streets: long-term observations and modelling 
of runoff losses and rainfall runoff transformation, Hydrol. Process., 25, 2161-2178, 2011.

Richards, L. A.: Capillary Conduction of Liquids Through Porous Mediums, Physics, 1, 318, https://doi.org/10.1063/1.1745010, 1931.

Rico-Ramirez, M. A., Liguori, S., and Schellart, A.: Quantifying radar rainfall uncertainties in urban drainage flow modelling, $\mathrm{J}$. Hydrol., 528, 17-28, 2015.

Rodriguez-Iturbe, I. and Mejia, J. M.: The design of rainfall networks in time and space, Water Resour. Res., 10, 713-728, https://doi.org/10.1029/WR010i004p00713, 1974.

Rossman, L. A.: Storm water management model user's manual, version 5.0, National Risk Management Research Laboratory, Office of Research and Development, US Environmental Protection Agency, Cincinnati, OH, USA, 2010.

Rummukainen, M.: Methods for statistical downscaling of GCM simulation, SWECLIM report, Rossby Centre, SMHI, Norrköping, Sweden, 1997.

Salvadore, E., Bronders, J., and Batelaan, O.: Hydrological modelling of urbanized catchments: A review and future directions, J. Hydrol., 529, 61-81, 2015.

Sangati, M., Borga, M., Rabuffeti, D., and Bechini, R.: Influence of rainfall and soil properties spatial aggregation on extreme flash flood response modelling: an evaluation based on the Sesia river basin, North Western Italy, Adv. Water Resour., 32, 1090-1106, 2009.

Schaake, J., Geyer, J., and Knapp, J.: Experimental examination of the rational method, Journal of Hydrological Division, 93, 353370, 1967.

Schellart, A., Shepherd, W., and Saul, A.: Influence of rainfall estimation error and spatial variability on sewer flow prediction at a small urban scale, Adv. Water Resour., 45, 65-75, https://doi.org/10.1016/j.advwatres.2011.10.012, 2011

Schertzer, D. and Lovejoy, S.: Multifractals, generalized scale invariance and complexity in geophysics, Int. J. Bifurcation Chaos, 21, 3417-3456, 2011.

Schilling, W.: Rainfall data for urban hydrology: What do we need?, Atmos. Res., 27, 5-21, 1991.

Segond, M.-L., Wheater, H. S., and Onof, C.: The significance of spatial rainfall representation for flood runoff estimation: A numerical evaluation based on the Lee catchment, UK, J. Hydrol., 347, 116-131, 2007.

Shamir, E., Imam, B., Morin, E., Gupta, H. V., and Sorooshian, S.: The role of hydrograph indices in parameter estimation of rainfall-runoff models, Hydrol. Process., 19, 2187-2207, 2005.

Shepherd, J. M.: Evidence of urban-induced precipitation variability in arid climate regimes, J. Arid Environ., 67, 607-628, 2006.

Shepherd, J. M., Pierce, H., and Negr, i. A. J.: Rainfall Modification by Major Urban Areas: Observations from Spaceborne Rain Radar on the TRMM Satellite, J. Appl. Meteor., 41, 689-701, 2002.

Singh, V. P.: Derivation of time of concentration, J. Hydrol., 30, 147-165, 1976

Singh, V. P.: Effect of spatial and temporal variability in rainfall and watershed characteristics on stream flow hydrographs, Hydrol. Process., 11, 1649-1669, 1997.

Smith, A. J., Baeck, M. L., Morrison, J. E., Sturevant-Rees, P., Turner-Gillespie, D. F., and Bates, P. D.: The regional hydrol- ogy of extreme floods in an urbanizing drainage basin, American Meterological Society, 3, 267-282, 2002.

Smith, A. J., Baeck, M. L., Villarini, G., Welty, C., Miller, A. J., and Krajewski, W. F.: Analyses of a long term, high resolution radar rainfall data set for the Baltimore metropolitan region, Water Resour. Res., 48, W04504, https://doi.org/10.1029/2011WR010641, 2012.

Smith, B. K., Smith, A. J., Baeck, M. L., Villarini, G., and Wright, D. B.: Spectrum of storm event hydrologic response in urban watersheds, Water Resour. Res., 49, 2649-2663, 2013.

Smith, B. K., Smith, A. J., Baeck, M. L., and Miller, A. J.: Exploring storage and runoff generation processes for urban flooding through a physically based watershed model, Water Resour. Res., 51, 1552-1569, 2015.

Smith, J. A., Bradley, A. A., and Baeck, M. L.: The space-time structure of extreme storm rainfall on the Southern Plains, J. Appl. Meteorol., 33, 1402-1417, 1994.

Smith, J. A., Baeck, M. L., Meierdiercks, K. L., Nelson, P. A., Miller, A. J., and Holland, E. J.: Field studies of the storm event hydrologic response in an urbanizing watershed, Water Resour. Res., 41, W10413, https://doi.org/10.1029/2004WR003712, 2005.

Sørup, H. J. D., Christensen, O. B., Arnbjerg-Nielsen, K., and Mikkelsen, P. S.: Downscaling future precipitation extremes to urban hydrology scales using a spatio-temporal Neyman-Scott weather generator, Hydrol. Earth Syst. Sci., 20, 1387-1403, https://doi.org/10.5194/hess-20-1387-2016, 2016.

Stahl, K. and Hisdal, H.: Hydroclimatology in: Hydrological Drought - Processes and Estimation Methods, Elvisier, Amsterdam, the Netherlands, 19-51, 2004.

Thorndahl, S., Smith, J. A., Baeck, M. L., and Krajewski, W. F.: Analyses of the temporal and spatial structures of heavy rainfall from a catalog of high-resolution radar rainfall fields, Atmos. Res., 144, 111-125, 2014.

Thorndahl, S., Einfalt, T., Willems, P., Nielsen, J. E., ten Veldhuis, M.-C., Arnbjerg-Nielsen, K., Rasmussen, M. R., and Molnar, P. Weather radar rainfall data in urban hydrology, Hydrol. Earth Syst. Sci., 21, 1359-1380, https://doi.org/10.5194/hess-21-13592017, 2017.

Tokarczyk, P., Leitao, J. P., Rieckermann, J., Schindler, K., and Blumensaat, F.: High-quality observation of surface imperviousness for urban runoff modelling using UAV imagery, Hydrol. Earth Syst. Sci., 19, 4215-4228, https://doi.org/10.5194/hess-19-42152015, 2015.

United States Department of Agriculture (USDA): Time of Concentration, in: National Engineering Handbook Hydrology, chap. 15, Part 630 Hydrology, eDirectives site, available at: https://www.nrcs.usda.gov/wps/portal/nrcs/detailfull/national/ water/manage/hydrology/?cid=stelprdb1043063 (last access: 26 July 2017), 2010.

van de Beek, C. Z., Leijnse, H., Stricker, J. N. M., Uijlenhoet, R., and Russchenberg, H. W. J.: Performance of high-resolution Xband radar for rainfall measurement in The Netherlands, Hydrol. Earth Syst. Sci., 14, 205-221, https://doi.org/10.5194/hess-14205-2010, 2010.

van de Giesen, N., Stomph, T., and de Ridder, N.: Surface runoff scale effects in West African watersheds: modeling and management options, Agr. Water Manage., 72, 109-130, 2005. 
van de Giesen, N., Stomph, T., Ebenezer Ajayi, A. E., and Bagayoko, F.: Scale effects in Hortonian surface runoff on agricultural slopes in West Africa: Field data and models, Agr. Ecosyst. Environ., 142, 95-101, 2011.

van de Ven, F. H. M.: Water balances of urban areas, Hydrological Processes and Water Management in Urban Areas, Proceedings of the Duisberg Symposium, 24-29 April 1988, Zoetermeer, the Netherlands, IAHS Publ., 198, 1990.

Van Loon, A. F.: Hydrological drought explaines, WIREs Water, 2, 359-392, 2015.

Versini, P. A., Gires, A., Abbes, J. B., Giangola-Murzyn, A., Tchinguirinskaia, I., and Schertzer, D.: Simulation of Green Roof Impact at Basin Scale by Using a Distributed RainfallRunoff Model, 13th International Conference on Urban Drainage (ICUD), 7-11 September 2014, Sarawak, Malaysia, 1-9, 2014.

Villarini, G., Mandapaka, P. V., Krajewski, W. F., and Moore, R. J.: Rainfall and sampling uncertainties: A rain gauge perspective, J. Geophys. Res.-Atmos., 113, D11102, https://doi.org/10.1029/2007jd009214, 2008.

Villarini, G., Seo, B. C., Serinaldi, F., and Krajewski, W. F.: Spatial and temporal modeling of radar rainfall uncertainties, Atmos. Res., 135-136, 91-101, https://doi.org/10.1016/j.atmosres.2013.09.007, 2014.

Wang, L. P., Ochoa-Rodriguez, S., Simoes, N., Onof, C., and Maksimovic, C.: Radar-raingauge data combination techniques: a revision and analysis of their suitability for urban hydrology, Water Sci. Technol., 68, 737-747, 2013.

Wang, L. P., Ochoa-Rodriguez, S., Onof, C., and Willems, P.: Singularity-sensitive gauge- based radar rainfall adjustment methods for urban hydrological applications, J. Hydrol., 531, 408-426, 2015a.

Wang, L. P., Ochoa-Rodriguez, S., van Assel, J., Pina, R. D., Pessemier, M., Kroll, S., Willems, P., and Onof, C.: Enhancement of radar rainfall estimates for urban hydrology through optical flow temporal interpolation and Bayesian gauge-based adjustement, J. Hydrol., 531, 408-426, https://doi.org/10.1016/j.jhydrol.2015.05.049, 2015b.
Wilby, R. and Wigley, T.: Downscaling general circulation model output: a review of methods and limitation, Prog. Phys. Geog., 21, 530-48, 1997.

Wilks, D. S. and Wilby, R. L.: The weather generation game: a review of stochastic weather models, Prog. Phys. Geog., 23, 329357, 1999.

Winchell, M., Gupta, H. V., and Sorooshian, S.: On the simulation of infiltration and saturation excess runoff using radar based rainfall estimates: Effects of algorithm uncertainty and pixel aggregation, Water Resour. Res., 34, 2655-2670, 1998.

WMO, W. M. O.: Guide to Meteorological Instruments and Methods of Observation, Seventh edition, WMO-No. 8, Geneva, Switzerland, 2008.

Wood, S. J., Jones, D. A., and Moore, R. J.: Static and dynamic calibration of radar data for hydrological use, Hydrol. Earth Syst. Sci., 4, 545-554, https://doi.org/10.5194/hess-4-545-2000, 2000.

Wright, D., Smith, J., Villarini, G., and Baeck, M.: Estimating the frequency of extreme rainfall using weather radar and stochastic storm transposition, J. Hydrol., 488, 150-165, 2013.

Wright, D., Smith, J., and Baeck, M.: Flood frequency analysis using radar rainfall fields and stochastic storm transposition, Water Resour. Res., 50, 1592-1615, 2014.

$\mathrm{Xu}, \mathrm{C}$. : From GCMs to river flow: a review of downscaling methods and hydrologic modelling approaches, Prog. Phys. Geog., 23, 229-249, 1999.

Yang, L., Smith, J. A., Baeck, M. L., and Zhang, Y.: Flash flooding in small urban watersheds: storm event hydrological response, Water Resour. Res., 52, 4571-4589, https://doi.org/10.1002/2015WR018326, 2016.

Yao, L., Wei, W., and Chen, L.: How does imperviousness impact teh urban rainfall-runoff process under various storm cases?, Ecol. Indic., 60, 893-905, 2016.

Zoppou, C.: Review of urban storm water models, Environ. Model. Softw, 16, 195-231, 2000. 